\title{
THE IMPACT OF UNITED STATES TAX POLICIES ON SECTORAL FOREIGN DIRECT INVESTMENT TO ASIA
}

Valerie Mercer-Blackman and Shiela Camingue-Romance

NO. 628

December 2020
ADB ECONOMICS WORKING PAPER SERIES 


\section{ADB Economics Working Paper Series}

\section{The Impact of United States Tax Policies on Sectoral Foreign Direct Investment to Asia}

Valerie Mercer-Blackman and Shiela Camingue-Romance

No. 628 | December 2020
Valerie Mercer-Blackman (vmercerblackman@ worldbank.org) is a senior economist at the World Bank and Shiela Camingue-Romance (scamingue@adb.org) is an economics officer at the Asian Development Bank.

We would like to thank Fahad Khan, Suzette Dagli, and Mara Clara Tayag for sharing the database, Yasuyuki Sawada and Abdul Abiad for comments, as well as participants of the first ADB Economics

Forum in January 2019. 
(C) 2020 Asian Development Bank 6 ADB Avenue, Mandaluyong City, 1550 Metro Manila, Philippines

Tel +632 8632 4444; Fax +63286362444

www.adb.org

Some rights reserved. Published in 2020.

ISSN 2313-5867 (print), 2313-5875 (electronic)

Publication Stock No. WPS200388-2

DOI: http://dx.doi.org/10.22617/WPS200388-2

The views expressed in this publication are those of the authors and do not necessarily reflect the views and policies of the Asian Development Bank (ADB) or its Board of Governors or the governments they represent.

ADB does not guarantee the accuracy of the data included in this publication and accepts no responsibility for any consequence of their use. The mention of specific companies or products of manufacturers does not imply that they are endorsed or recommended by ADB in preference to others of a similar nature that are not mentioned.

By making any designation of or reference to a particular territory or geographic area, or by using the term "country" in this document, $A D B$ does not intend to make any judgments as to the legal or other status of any territory or area.

This work is available under the Creative Commons Attribution 3.0 IGO license (CC BY 3.0 IGO)

https://creativecommons.org/licenses/by/3.o/igo/. By using the content of this publication, you agree to be bound by the terms of this license. For attribution, translations, adaptations, and permissions, please read the provisions and terms of use at https://www.adb.org/terms-use\#openaccess.

This CC license does not apply to non-ADB copyright materials in this publication. If the material is attributed to another source, please contact the copyright owner or publisher of that source for permission to reproduce it. $\mathrm{ADB}$ cannot be held liable for any claims that arise as a result of your use of the material.

Please contact pubsmarketing@adb.org if you have questions or comments with respect to content, or if you wish to obtain copyright permission for your intended use that does not fall within these terms, or for permission to use the ADB logo.

Corrigenda to ADB publications may be found at http://www.adb.org/publications/corrigenda.

Note:

In this publication, “\$” refers to United States dollars.

The ADB Economics Working Paper Series presents data, information, and/or findings from ongoing research and studies to encourage exchange of ideas and to elicit comment and feedback about development issues in Asia and the Pacific. Since papers in this series are intended for quick and easy dissemination, the content may or may not be fully edited and may later be modified for final publication. 


\section{CONTENTS}

TABLES, FIGURES, AND BOX iv

ABSTRACT

$\begin{array}{ll}\text { I. INTRODUCTION } & 1\end{array}$

II. WHAT HAS HAPPENED TO THE UNITED STATES' FOREIGN DIRECT 2

INVESTMENT IN ASIA?

III. WHAT DRIVES FOREIGN DIRECT INVESTMENT, AND HOW IMPORTANT 7 ARE TAXES AND INCENTIVES?

IV. RECENT CHANGES IN UNITED STATES TAX LAW: ANY IMPACT 9 ON ASIA-BOUND FOREIGN DIRECT INVESTMENT?

A. The United States Tax and Jobs Act 9

B. Incentives for Repatriation of Profits or Investment Back to the United States 11

V. THE IMPACT OF THE TAXES DEPENDS ON THE SECTOR 14

A. Data Descriptions and Methodology 14

B. Empirical Strategy 19

C. Estimation Results for the Full Sample 19

D. Estimation Results by Sectors 23

E. Possible Impact on Some Sectors 26

VI. CONCLUSIONS AND POLICY RECOMMENDATIONS 27

$\begin{array}{lr}\text { APPENDIX } & 29\end{array}$

$\begin{array}{lc}\text { REFERENCES } & 32\end{array}$ 


\section{TABLES, FIGURES, AND BOX}

\section{TABLES}

1 Corporate Income Tax Rates and Foreign Direct Investment Restrictiveness, Selected Developing Economies

2 Description of Variables and Summary Statistics

3 Regression Results (Fixed Effects Model), Full Sample

4 Regression Results (Fixed Effects Model), Developing Asia versus Nondeveloping Asia

5 Share of United States Greenfield Outward Foreign Direct Investment, 2003-2017

6 Regression Results (Fixed Effects Model), Full Sample by Sector Motivation Groups

$7 \quad$ Semi-elasticity and Projections on Foreign Direct Investment of a Change in United States Corporate Tax Rate from 36\% to 21\%

A.1 Classification of Sectors by Motivation Factor

A.2 Sign, Statistical Significance, and Robustness of Main Coefficients in Sector-Specific Regressions

\section{FIGURES}

1 Total Greenfield Investments to Developing Asia, 2003-2018

2 Total United States Outward Greenfield Investments, by Destination

3 Total Greenfield Investment in Developing Asia, by Sector

$4 \quad$ United States Outbound Foreign Direct Investment, by Motivation and Sectors

5 Shares of United States Inward Foreign Direct Investment by Sector

$6 \quad$ United States Equity Investments Abroad

\section{BOX}




\begin{abstract}
How sensitive is inward foreign direct investment (FDI) from the United States (US) to developing Asia to corporate tax rates? This is a relevant question given the sweeping US tax bill effective in 2018, which provided incentives for US corporations abroad to repatriate profits. Using panel data at the country and sector level, we find that the effects are quite different across sectors, and that controlling for other factors such as market size, costs, openness, and the business environment, the corporate income tax rate differential is generally not statistically significant, including for global value chain-related FDI to developing Asia. It does have a small effect on service sectors such as financial intermediation and business services where sunk costs are small.
\end{abstract}

Keywords: corporate tax, FDI, fiscal policy, foreign investment, Tax and Jobs Act, sectors

JEL codes: F21, H30, H25 



\section{INTRODUCTION}

The profile of foreign direct investment (FDI) flows has been changing dramatically in developing Asia. ${ }^{1}$ There are economies which have moved from net inward FDI receivers to FDI investors abroad over the last 10 years. The focus of this paper will be on greenfield FDI from the United States (US), particularly into productive sectors in developing Asia.

The question we will address is how sensitive US foreign investors are to corporate tax changes, particularly FDI to Asia. In economic terms, we investigate the size and significance of the semi-elasticity of inward FDI from the US to changes in the US's corporate tax rate. This is a relevant question given the sweeping tax bill passed in December 2017 in the US, which provided important incentives for US corporations working abroad to repatriate profits back to the US and to heavily invest in capital-intensive production at home. It also lowered statutory tax rates for US resident companies investing both at home and abroad by almost $45 \%$ to levels below average corporate tax rates in Asia.

Preliminary data suggests that in the past 2 years, outflows from the US have fallen, although not dramatically, and most seem to be profit remittances taking advantage of the lower tax rates rather than increased reinvestment in fixed capital in the US. It is also unclear whether some of these trends relate to the trade conflict which has discouraged investment flows in general, particularly between the US and the People's Republic of China (PRC). However, some inferences can be made based on past relationships between $\mathrm{FDI}$ and the tax rate.

While there are many studies that analyze the impact of tax changes on investment, very few consider investment at the sectoral level. We divide US FDI by production sector to understand whether the sensitivity of US FDI to the host country tax rate varies by target industry. The hypothesis is that investors are attracted to specific sectors for different reasons: extractive sectors may depend on commodity prices, low-tech manufacturing may depend on labor costs, services on the size and regulatory environment of the domestic host market, etc. This in turn determines foreign investors' sensitivity to tax policy changes.

We find that the tax differential is only significant for US FDI in a few sectors, and only robustly in financial intermediation and business services. US investment is likely sensitive to relative tax changes in those services perhaps because funding in those sectors is by nature more mobile and amenable to US companies diversifying capital to minimize their tax liabilities. Still, the impact is small: a 1\% reduction in the income tax rate differential is estimated to raise FDI by 0.19 in business services, and 0.14 in financial intermediation. Other than these, our results are consistent with the hypotheses that in emerging markets, other factors such as governance, exchange rate differentials, and level of development matter much more to US investors. Moreover, the results reinforce the hypothesis that specific characteristics are more important for some sectors than for others.

The next section discusses recent trends in greenfield FDI in developing Asia, particularly from the US. Section III reviews the relevant literature on FDI determinants and taxation. Section IV discusses the 2017 tax law changes and examines actual and potential impact on FDI flows. Section $V$ describes the model and data, and presents the results of the estimations. Section VI concludes.

Developing Asia refers to the 45 developing member economies of the Asian Development Bank (excluding Japan), and includes the newly industrialized economies of Hong Kong, China; the Republic of Korea; Singapore; and Taipei,China. 


\section{WHAT HAS HAPPENED TO THE UNITED STATES' FOREIGN DIRECT INVESTMENT IN ASIA?}

By its nature, FDI tends to be lumpy and driven by large project starts during a short time-period, especially cross-border mergers and acquisitions (M\&A). This paper will focus on greenfield investment because it is more directly related to physical capital sunk costs in a project-not just a change of asset ownership-and thus better indicates productive investments.

FDI inflows of new "greenfield" projects into developing Asia reached the equivalent of an estimated $1.7 \%$ of gross domestic product (GDP) in 2016, bouncing back from a low of $1.2 \%$ in 2012 in the wake of the global financial crisis of 2008-2009 (Figure 1). In 2017, greenfield FDI was only about $0.9 \%$ of GDP on account of the uncertain global economic environment, particularly from the US, but mostly due to a clampdown of potential roundtripping of PRC real estate investments through Hong Kong, China amid PRC restrictions on domestic real estate investments ${ }^{2}$. By end-2018, greenfield FDI rose to $1.6 \%$ of GDP. The sectors receiving FDI are diverse, with oil, gas and mining; machinery, transport equipment and electronics; and related business services taking prominent shares in the total. Over the 15 years to 2018, the largest recipients of greenfield FDI to developing Asia as a share of total were the PRC, India, and ASEAN-5 with a share of $34.0 \%, 15.9 \%$, and $26.3 \%$, respectively. ${ }^{3}$

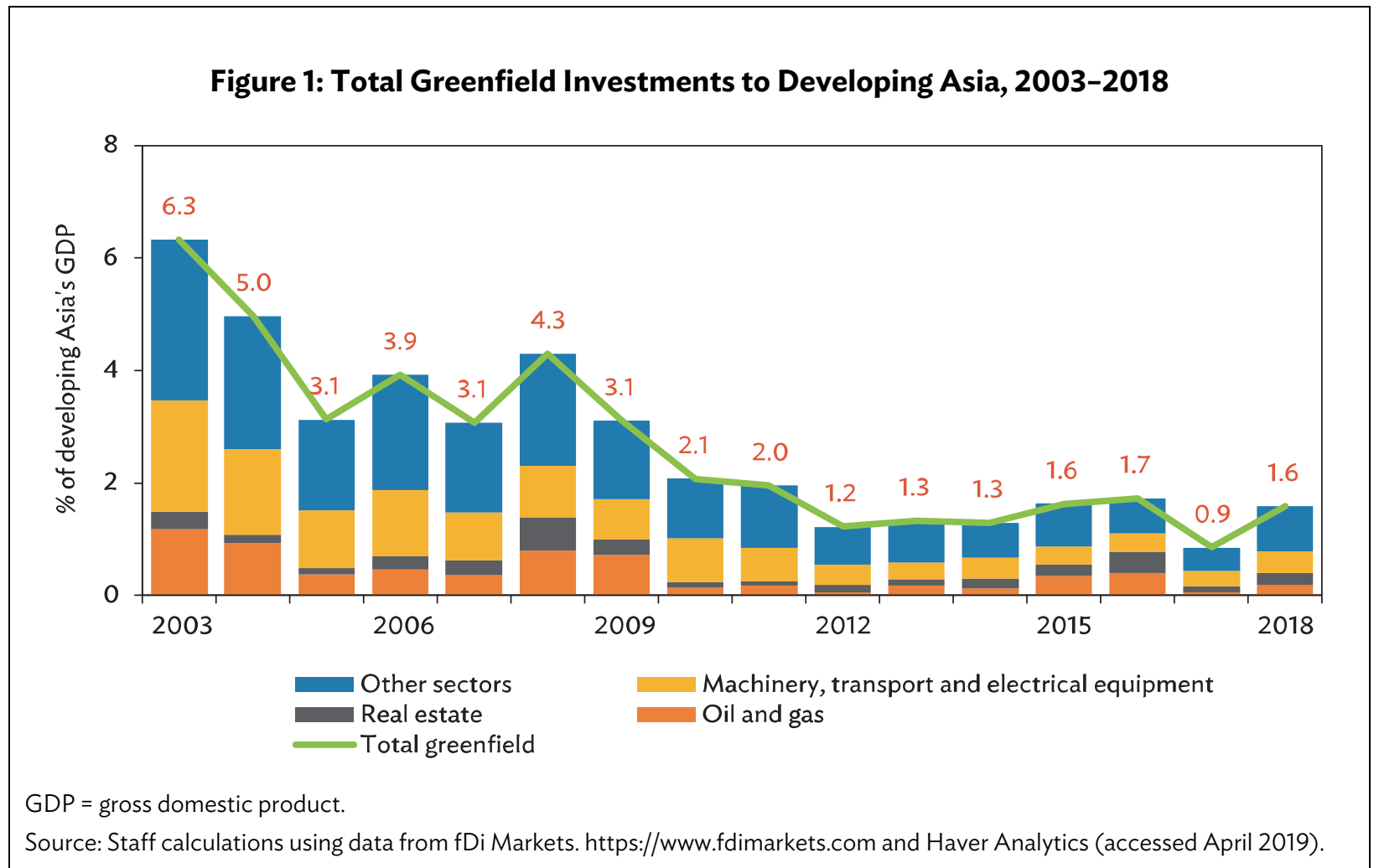

2 See chapter 3 of ADB (2018a) for a detailed explanation of the breakdown. The number of projects, which is a more updated indicator of greenfield FDI, did not decline as much. Indeed, the number of greenfield projects into the region has been mostly steady since 2012.

3 ASEAN-5 refers to the Association of Southeast Asian Nations, which is composed of five countriesIndonesia, Malaysia, the Philippines, Thailand, and Viet Nam. 
FDI from the US to developing Asia has become more prominent. Most of the US'S total greenfield FDI goes elsewhere in the world, particularly to other Organisation for Economic Cooperation and Development (OECD) countries, and from the total, almost two-thirds of FDI bound for developing Asia goes to the PRC and India alone (Figure 2). As a share of developing Asia's GDP, US inward FDI was $0.4 \%$ on average between 2007 and 2017 with a declining trend. 42\% of the total FDI is greenfield (new project) investment. The rest finances M\&A. As a share of total US greenfield FDI, almost a quarter of US inbound investment goes there.

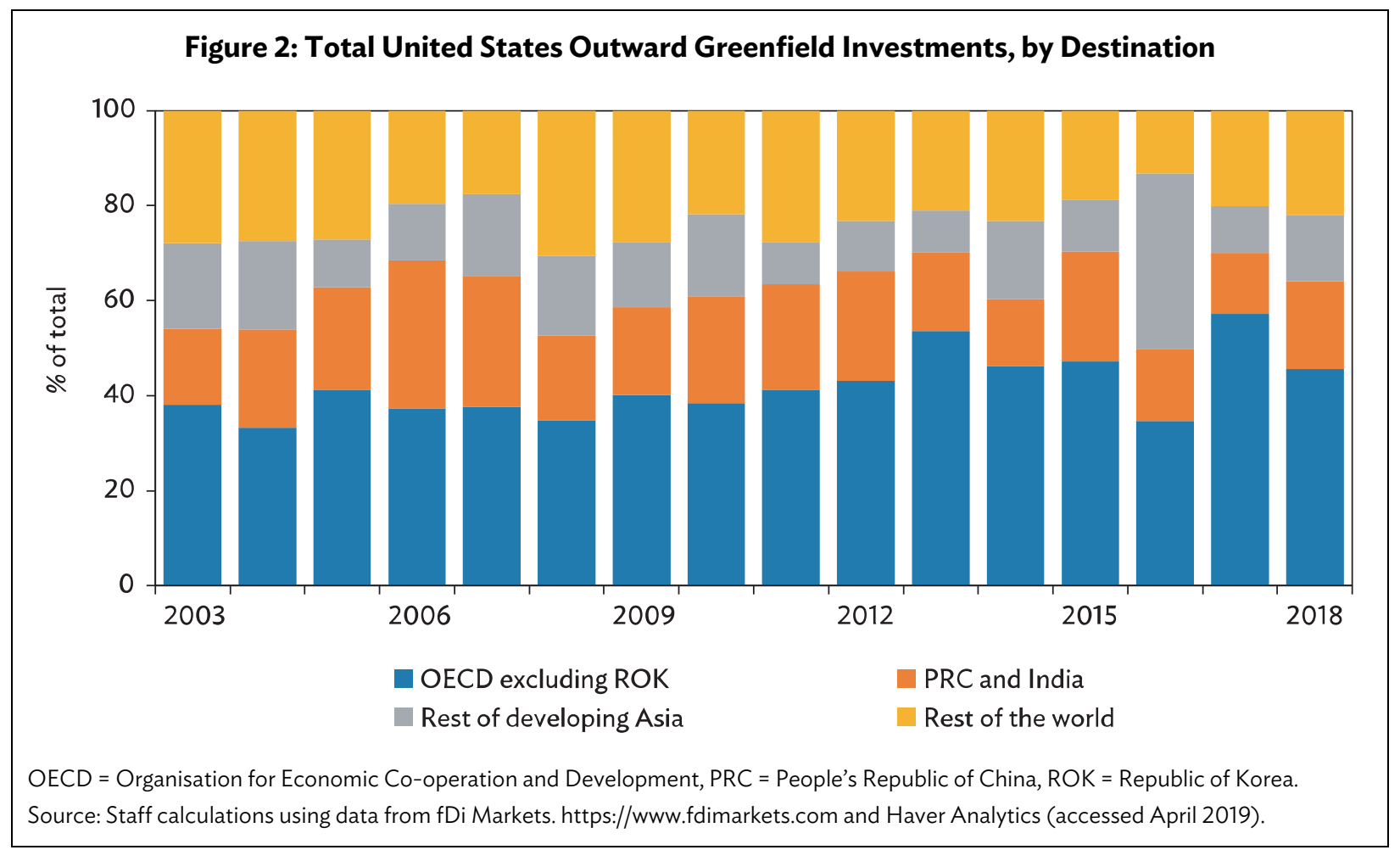

Moreover, the sectoral distribution is quite diversified, with the majority of US FDI going to extractive resource industries (particularly oil and gas in Central Asia), consumer-oriented manufacturing geared toward the host country markets, and investments in high-tech sectors tightly linked to global value chains (GVCs). Despite some fluctuations over time, this sectoral distribution is not much different to the US's global FDI presence (Figure 3). The US provides about $17 \%$ of developing Asia's greenfield FDI (equivalent to a third of its outbound greenfield FDI). ${ }^{4}$

4 Outward FDI from developing Asia - particularly the PRC - has been growing steadily as well, reaching 15\% of the region's GDP in 2017 on average, but is still small relative to the US outward FDI of 24\% of its GDP. It fell in 2018 and the first half of 2019 , most likely due to the impact of the US-PRC trade conflict and related restrictions. 
Figure 3: Total Greenfield Investment in Developing Asia, by Sector

Agriculture, natural resources, mining and quarrying

Telecommunications, ICT and post

Machinery, and transport equipment, and its repair

Petrochemicals, refining, rubber and plastics.

Business activities and renting of machinery and equipment

Transport services

Financial intermediation

Basic manufacturing and services, construction and other

Electrical and optical equipment

Tourism, hotels, restaurants

Food, beverages and tobacco

Metals and nonmetallic minerals

Real estate activities

Other
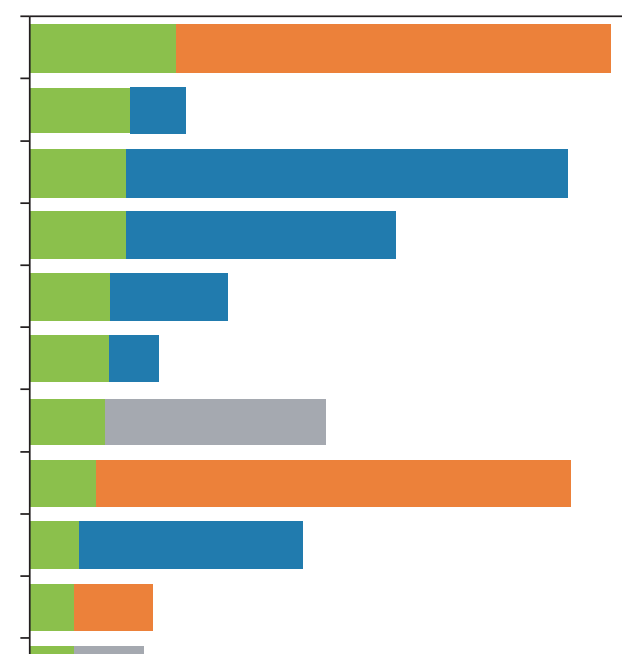

Other

0

0.1

0.2

Total by main investor motivation:

$\%$ of GDP (average 2013-2017)

GVC specific $\square$ Specific to location $\square$ Specific to host market size $\square$ Other $\square$ of which: from the US

GDP = gross domestic product, GVC = global value chain, ICT = information and communication technology, US = United States Source: Staff calculations using data from fDi Markets. https://www.fdimarkets.com and Haver Analytics (accessed April 2019).

This paper's focus is the impact of US tax policies on greenfield investments by sectors. Thus, we look at FDI disaggregated into 18 production sectors, but those sectors in turn can be grouped into four analytical groups based on the motivation of investors as defined in the FDI literature (see, for example, ADB 2015).

(i) Sectors that attract efficiency-seeking investors, particularly firms immersed in GVCs. Investors are less interested in the local market and more in installing a production process in the host country strategically to minimize production costs.

(ii) Sectors more attractive to foreign investors interested in expanding in the domestic host market.

(iii) Sectors that attract resource-seeking investors, which could be both vertical (extractive) or horizontal (if the local market is important).

(iv) Other sectors.

While it is impossible to derive a foreign investor's motivation solely by the sector where they choose to invest, it is a good approximation given the similarity of the nature of the production processes within sectors. Based on these groups, the sectoral composition of US outbound FDI during the 20032017 period shows that about half of their greenfield FDI is in GVC, efficiency-related sectors (Figure 4, 
blue-shaded area). Multinational entities in GVC sectors are more easily able to distribute activities across countries to minimize their costs and tax bills.

Figure 4: United States Outbound Foreign Direct Investment, by Motivation and Sectors (Average for 2003-2017, \$ billion)

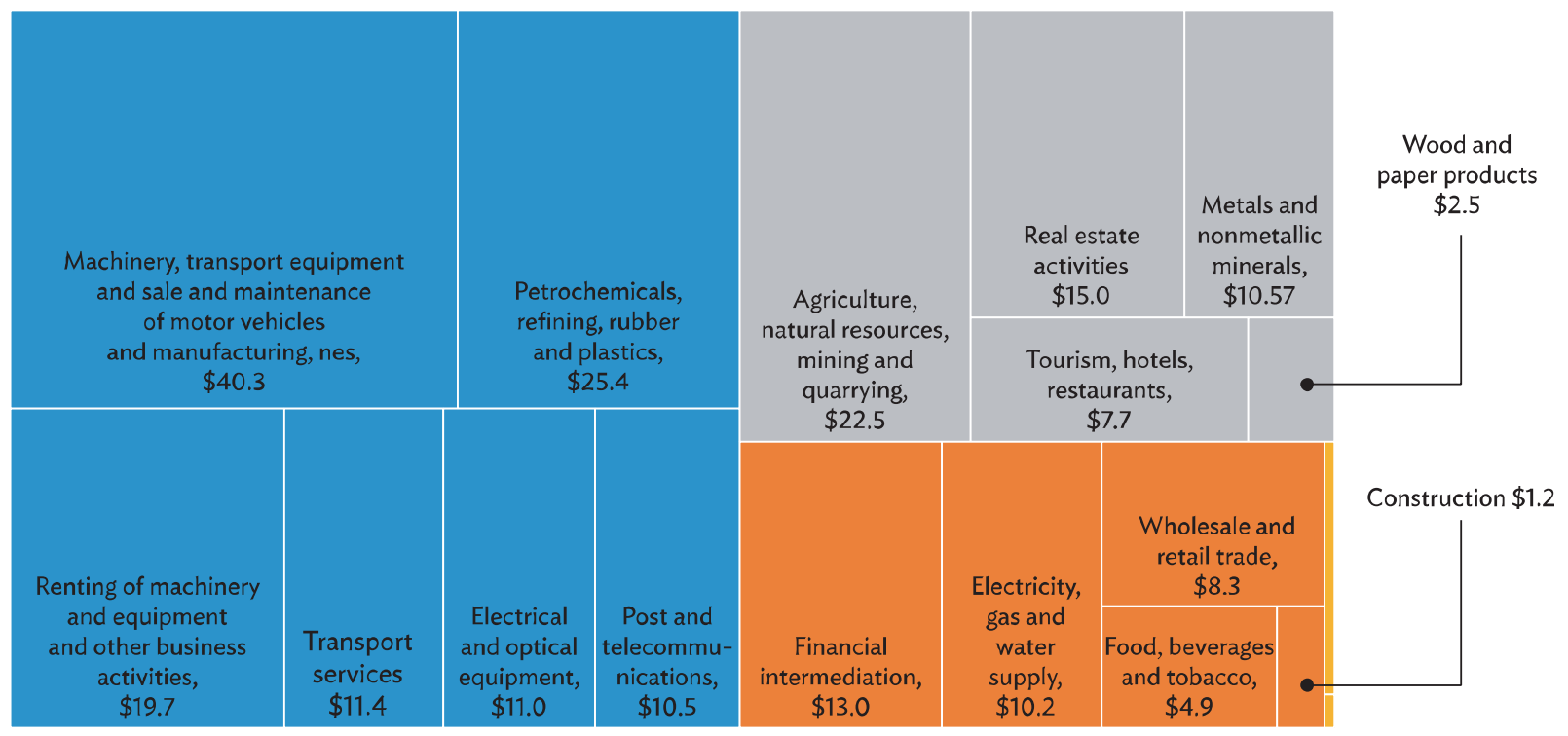

GVC, effciency related Large market seeking Location specific, resource seeking $\square$ Other

GVC = global value chain.

Source: Staff calculations using data from fDi Markets. https://www.fdimarkets.com and Haver Analytics (accessed April 2019).

Other than tourism, business services, and electrical and optical equipment which are more important in developing Asia, the distribution of investment across sectors of US FDI is about the same inside and outside of developing Asia (Figure 5).

FDI growth by its nature is lumpy-once an investment is implemented it will manifest as a surge of funds within a short period of time, and this is even more salient for sectorial FDI. For example, the share of US outbound FDI to developing Asia surged to 36\% in 2016 and then back to 15\% in 2017, mostly explained by a large oil and gas investment in Kazakhstan although exploration had already started many years ago. 


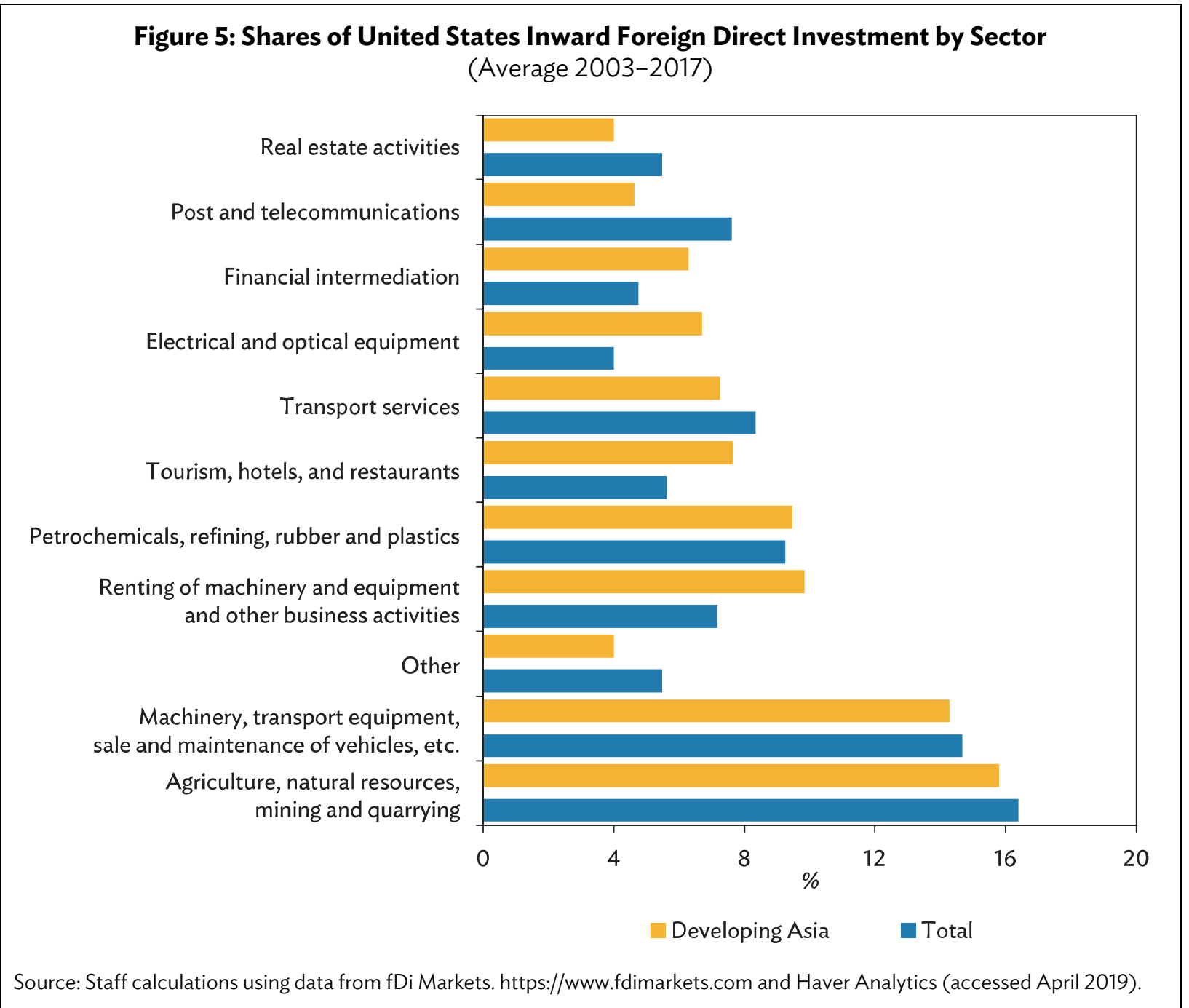

Another data issue is the difficulty of identifying the ultimate residency of the foreign investor. OECD (2019) and UNCTAD (2019) have devoted considerable resources to account for this, which is notoriously hard due to transfer pricing practices and lack of coordination on foreign investment statistics across countries. Since our main data source, fDi Markets, is at the firm level, the ultimate source is mostly identifiable. However, it is not always clear whether data for the more recent years is based on planned projects or actual implementation. To partially counteract this, we also checked trends using recent investment flows from the balance of payments statistics (although this would also include M\&A FDI).

The difference in sources and definitions sometimes leads to seemingly contradictory outcomes. For example, US greenfield FDI to developing Asia and the PRC using firm-level annual fDi Markets data rose in 2018 relative to 2017-and quite substantially to some countries (see also ADB 2019a, 2019b). Yet national data from the PRC authorities and the US Bureau of Economic Analysis shows that US FDI to developing Asia and the PRC began to fall in the first half of $2018 .{ }^{5} \mathrm{It}$ is possible that greenfield FDI, rose but more liquid investment in financial assets and M\&A investment fell, more than offsetting the

5 See Bureau of Economic Analysis. https://www.bea.gov/international/di1usdbal (accessed April 2019). 
rise in greenfield FDI. This reflects the difficulty of measuring whether investment flows represent real financing of physical capital, not cross-border movements of investment vehicles such as specialpurposed entities that declare residency to minimize their tax liability. According to new evidence (see Damgaard, Elkjaer, and Johannesen 2019), these global flows may account for as much as $40 \%$ of reported FDI flows. This complicates the interpretation of more recent data but is less of a concern for historical data which is collected at the firm and sectoral level by fDi Markets. The information is revised for past years, and the residency of the ultimate investor can be traced.

Before examining whether recent tax reforms could have had an impact on this pattern, a quick review of the literature on FDI and tax incentives is in order.

\section{WHAT DRIVES FOREIGN DIRECT INVESTMENT, AND HOW IMPORTANT ARE TAXES AND INCENTIVES?}

The literature on what motivates foreign investment is quite broad. ADB (2015 emphasizes two major motives: horizontal and vertical. Multinationals that engage in horizontal investments want to establish production abroad in order to serve local markets. In contrast, vertical investors serve to geographically allocate a company's production chain with the aim of exploiting interlocational differences in relative factor endowments. While differentials in after-tax production costs are an important consideration for either type, the horizontal type of investor will be more concerned about the business environment (including security, rule of law, control of corruption, fiscal policy stability, etc.); while the vertical type will be more interested in specific production conditions, and oftentimes may be operating in a special regime of free-trade zones for exports. Moreover, the horizontal investor will likely have higher sunk costs in the host country and is only likely to fully relocate or uproot from the host country if the environment deteriorates drastically and unusually fast. Therefore, they are much less mobile but have a longer-term horizon and are also less swayed by generous initial incentives such as tax holidays. ${ }^{6}$

Studies focused on emerging markets find that overly generous fiscal incentives and low tax rates do not always work to attract investors with a long-term perspective. Morisset and Pirnia (2001) present evidence that low taxes are a signal that the host government will have less funds for spending on infrastructure and education, for example, which ultimately reduces the attractiveness of the jurisdiction. Using cross-country data on 41 developing market economies, James (2009) finds that fiscal incentives (which could include low corporate tax rates) are particularly ineffective in attracting investment in countries with poor investment climates. It also explains why some fiscal incentives have been used successfully to encourage investment in some countries while failing in others. For example, free-trade industrial zones, which became popular in the late 1970s, are prevalent everywhere including the US. Therefore, as the standard has become that of free-trade zones, in the same way as corporate tax rates have been on a downward spiral in the last 2 decades across the world (base erosion), installing an additional free-trade or industrial zone is unlikely to spur additional FDI in any given host country. Moreover, many low-income countries have very liberal capital account rules and tax incentives for investors yet receive very little FDI.

6 This summarizes the empirical work conducted by the World Bank-IFC's Foreign Investment Advisory Service over several years. The sectoral composition used in this analysis will allow us to study in more detail the motivation of investors and the impact of tax policies. 
For the US, recent analysis suggests that the relatively high corporate tax rate mattered sufficiently to create perverse incentives for foreign investors. Regardless of revenue considerations, ${ }^{7}$ various papers (e.g., Hines 2017, Djankov et al. 2010) have presented evidence that high relative business tax burden impedes competitiveness. Looking specifically at the US, Hines argues that high tax rates - coupled with a worldwide tax base system - created incentives for firms to engage in so-called "corporate inversions," in which corporations would undertake legal transactions designed to change their tax homes, leaving the US and setting up residence in foreign countries with lower tax rates and territorial tax systems (see also Desai and Hines 2002). Other evidence shows that levels and locations of outward FDI from the US is highly responsive to local tax rates (Hebous, Ruf, and Weichenrieder 2010); and multinational firms located in countries with worldwide tax systems and high tax rates are less capable than other firms of competing for foreign investment in low-tax locations (Hines 1996, Barrios et al. 2012). However, since taxes on profits implicitly reduce the after-tax costs (since businesses are entitled to deduct at least a portion of costs against their taxable incomes), then targeting low-cost jurisdictions for production also reduced deductions. Nonetheless, US tax corporations constantly searched for ways to reduce the tax burden including investing in tax-preferred activities such as research and development or by locating tax residence of profitable investments in low-tax locations. Hines (2017) estimates that these production reallocation decisions reduced the income tax liability of these US corporations by $4 \%$ on average. Other studies in OECD countries, have found that higher corporate taxes deter investment with an estimated semi-elasticity of $-3 \%$, but large variation (De Mooij and Ederveen 2008). Desai, Foley, and Hines (2002) find that a 10\% increase in the corporate tax rate reduces US multinational investment by $5 \%$.

The economic literature on cross-country studies which include emerging markets, in contrast, suggests that tax rates are generally not a priority consideration for investors when deciding about location. ${ }^{8}$ Studies on emerging markets show that once other factors are considered-such as the size of the market, availability of natural resources, business environment, and host country potential for demand growth - tax differentials between the guest and the host country tend to be unimportant (Echandi, Krajcovicova, and Qiang 2015; James 2009). Instead, research finds that emerging markets that strive to improve the quality and variety of their products can attract FDI, regardless of tax regime. For example, exports from the PRC located where foreign investors set foot tend to see improvements in the quality of exports (Swenson 2008). For investors with a long-term horizon targeting natural resources, the literature suggests that certainty about the fiscal regime and governance are more important than the tax rate itself (Hassett and Metcalf 1999, Hvozdyk and Mercer-Blackman 2009).

A much less explored approach in the literature is to look at the different effects on taxes depending on the sector. This partly reflects data scarcity, of course. Stöwhase (2005) and Obeng (2014), two studies that took a sectoral approach, found that the impact of taxation can vary substantially across sectors.

There is also a debate about which is the right indicator of the tax burden. Fortunately, using actual versus effective tax rates does not seem to change the ordering when comparing burdens across major

7 Assuming that corporate taxes are reduced but not offset by an increase in other taxes that may make a policy package revenue neutral.

8 Morisset and Pirnia (2001) also show evidence that, when other factors such as political and economic stability, infrastructure and transport costs are about equal between potential locations, taxes may exert a significant impact. This is evidenced by the growing tax competition in regional groupings such as the European Union or at the subregional level within one country (e.g., the US). 
economies (see, for example, Price Waterhouse Cooper 2016). ${ }^{9}$ While special exemptions and fiscal incentives generally reduce the average effective tax rate of US corporations by between 3 and 8 percentage points, this is true in most countries around the world. Markle and Shackelford (2014) use data on over 9,000 multinationals from 87 countries and controlling for size find that the average effective tax rate for US companies is about $28 \%$, but still the second highest for major countries after Japan. Most importantly, while the effective rates were lower than the statutory rates, the rankings seem to be mostly preserved.

\section{RECENT CHANGES IN UNITED STATES TAX LAW: ANY IMPACT ON ASIA-BOUND FOREIGN DIRECT INVESTMENT?}

\section{A. The United States Tax and Jobs Act}

Until December 2017, the US statutory corporate tax rate was very high by international standards. The top combined federal and average net state corporate income tax rate, at 38.9\%, was the highest among the 35 OECD member countries and 14.7 percentage points above the OECD average of $24.2 \%$.

The December 2017 US "Tax and Jobs Act" (henceforth TJA) changed this very quickly, reducing the statutory corporate tax rate to $21 \%$, including the elimination of the corporate alternative minimum tax rate (which was a safeguard measure to ensure all companies pay at least a fair share). The $21 \%$ tax rate also applies to profits earned abroad and repatriated back to the US: profits earned before 2018 can be repatriated at a reduced rate of 15.5\% for cash and $8 \%$ for illiquid assets. Most incentives such as deductions for research and development expenditures, limited loss carry-forward, and the 16\% capital gains tax rate were maintained. In addition, businesses can fully write off the value of investments in new plant and equipment until 2022; and the tax base shifted to a partial territorial system in which US firms investing abroad are exempt from US taxes (see Box 1 and Joint Committee on Taxation [2017], for details).

The immediate impact of the TJA on short-term economic activity, coupled with other factors, created an important stimulus effect on the US economy. GDP grew 2.9\% in 2018 from 2.2\% in 2017. Specific impacts from the business sector (discussed below) were palpable. However, the tailwinds of global trade growth which spurred US consumption coupled with additional fiscal spending also contributed to the higher US GDP growth in early 2018. This also created a knock-on effect for developing Asian economies during the first part of 2018. The seemingly positive impact on growth of the TJA over the short term was in some ways expected. Over the long term, however, implications could be negative, particularly because some of the redistributive provisions are set to expire in $2025 .^{\circ}$

9 In a comparison of tax burden among OECD studies, Price Waterhouse Cooper (2016) found that the US corporate effective tax rate ranked in the highest $12 \%$ of the respective comparison countries until 2018 and thus is relatively high by international standards. Among these four studies, the US corporate effective tax rate was between $26 \%$ and $114 \%$ higher than the average for the comparison countries.

10 Joint Committee on Taxation (2017) has pointed out some negative implications of the TJA reform. First, tax cuts were estimated to have a negative effect on the US budget deficit and debt, adding 5.3 percentage points of GDP to the Federal debt over 10 years. Second, there was a concern that high capital spending in the short term could lead to overheating. Finally, most of the benefits of the reform over the long term accrue to the top 10\% richest households, reducing further education, health, and employment opportunities for the bottom $90 \%$ of households by income. The skewness of the benefits across the income spectrum reduced its multiplier effect. 
US corporate taxes are now clearly competitive with those of other Asian economies, even considering foreign investment restrictions as measured by the FDI regulatory restrictiveness index (FDI index), as a result of the TJA (Table 1)." This FDI index by sector will be considered in the empirical section below.

\section{Table 1: Corporate Income Tax Rates and Foreign Direct Investment Restrictiveness, Selected Developing Economies}

\begin{tabular}{|c|c|c|}
\hline Economy & Corporate Income Tax Rates & $\begin{array}{l}\text { FDI } \\
\text { Index }\end{array}$ \\
\hline Brunei Darussalam & $18.5 \%$; $55 \%$ for oil and gas companies & 0.327 \\
\hline Cambodia & $20 \% ; 30 \%$ for oil and gas production, exploration, and exploitation of natural resources & 0.052 \\
\hline Hong Kong, China & 16.5\%; two-tiered Profit Tax regime on or after 1 April 2018 & $\ldots$ \\
\hline India & $30 \%$ for Indian companies; $40 \%$ for foreign companies & 0.212 \\
\hline Indonesia & $25 \% ; 20 \%$ for nonresident companies in the form of Permanent Establishment & 0.315 \\
\hline Lao PDR & $24 \%$ with a $5 \%$ reduction for companies listed in the Lao PDR stock exchange & 0.187 \\
\hline Malaysia & $24 \%$ but $18 \%$ for Malaysian resident small and medium-sized enterprises & 0.211 \\
\hline Myanmar (average) & $\begin{array}{l}25 \% \text { for companies established under the Myanmar Foreign Investment Law, } \\
\text { otherwise } 5 \%-40 \%\end{array}$ & 0.356 \\
\hline $\begin{array}{l}\text { People's Republic of } \\
\text { China }\end{array}$ & $25 \% ; 15 \%$ for high and new technology enterprises & 0.327 \\
\hline Philippines & $\begin{array}{l}30 \% \text { on net income for resident companies, or } 2 \% \text { based on gross income; } 30 \% \text { on } \\
\text { gross income for nonresident companies }\end{array}$ & 0.398 \\
\hline Singapore (strict) & $17 \%$ & $\ldots$ \\
\hline Thailand & $\begin{array}{l}20 \% \text { on net worldwide income; } 30 \% \text { on foreign companies for earnings in Thailand; } 3 \% \\
\text { of gross receipts for transport companies }\end{array}$ & $\ldots$ \\
\hline Viet Nam & $20 \% ; 32 \%-50 \%$ for oil and gas enterprises & 0.115 \\
\hline United States & $35 \%$ excluding deductions but $21 \%$ starting in 2018 , plus state taxes of $3 \%-5 \%$ & 0.089 \\
\hline OECD average & $\begin{array}{l}22.34 \% \text { for corporate income tax; } 22.2 \% \text { excluding deductions for subnational taxes; } \\
24.8 \% \text { for combined corporate income tax }\end{array}$ & 0.067 \\
\hline
\end{tabular}

... = not available; $\mathrm{FDI}=$ foreign direct investment, Lao PDR = Lao People's Democratic Republic, $\mathrm{OECD}=$ Organisation for Economic Co-operation and Development.

Note: FDI index is based on the OECD FDI regulatory restrictiveness index, where: $0=$ close, $1=$ open. FDI regulatory restrictiveness index gauges the restrictiveness of an economy's FDI rules (see section $\mathrm{V}$ below and Table 2 for more details).

Sources: Organisation for Economic Co-operation and Development. http://stats.oecd.org, https://www.oecd.org/investment/fdiindex.htm; Price Waterhouse Cooper. Worldwide Tax Summaries. https://www.pwc.com/gx/en/services/tax/worldwide-tax-summaries.html; Asia Briefing. https://www.asiabriefing.com/news/2014/12/analysis-asias-tax-rates-part-one-corporate-income-tax; KPMG. https://home.kpmg/xx/en/home/services/tax/tax-tools-and-resources/tax-rates-online/corporate-tax-rates-table.html (all accessed 23 March 2018).

1 See Organisation for Economic Co-operation and Development. https://www.oecd.org/investment/fdiindex.htm (accessed 23 March 2018). 


\section{Box: Features of the United States 2017 Tax and Jobs Act Relevant for Foreign Investors}

Corporate Tax Rate. Cuts corporate federal income tax rate permanently to 21\% from 35\%, as of 1 January 2018.

Corporate Alternative Minimum Tax. Repeals the $20 \%$ corporate alternative minimum tax, set up to ensure profitable corporations pay at least some tax.

Territorial System. Exempts United States (US) corporations from US taxes on most future foreign profits, ending the present worldwide system of taxing profits of all US-based corporations, no matter where they are earned. This would align the US tax code with most other countries and undercut incentives to invest in many offshore tax havens.

Repatriation. Sets a one-time mandatory tax of $8 \%$ on illiquid assets and $15.5 \%$ on cash, and that rule would be rendered obsolete by the territorial system. In general, newly enacted section 965 of the Internal Revenue Code imposes a transition tax on untaxed foreign earnings of foreign subsidiaries of US companies by deeming those earnings to be repatriated. Foreign earnings held in the form of cash and cash equivalents are taxed at a 15.5\% rate, and the remaining earnings are taxed at an $8 \%$ rate. The transition tax generally may be paid in installments over an 8 -year period.

Anti-base Erosion Measures. Prevents companies from shifting profits out of the US to lower-tax jurisdictions abroad. Sets an alternative minimum tax on payments between US corporations and foreign affiliates, and limits on shifting corporate income through transfers of intangible property.

Capital Expensing. Allows businesses to immediately write off, or expense, the full value of investments in new plant and equipment for 5 years, then gradually eliminates this 100\% expensing over 5 years beginning in year 6 . Also makes changes to permit for more expensing by small businesses. Capital investment incentives in the form of current US bonus depreciation that permits firms to deduct $50 \%$ of the expense of eligible equipment investment, and rapid depreciation of other investment expenses, encourages economic activity by firms in capital-intensive industries and similar lines of business, implicitly at the expense of firms in other industries and lines of business.

Interest Deduction Limit. Caps business deductions for debt interest payments at 30\% of taxable income, regardless of deductions for depreciation, amortization, or depletion.

Sources: Becker, Amanda, and David Morgan. 2017. "What's in the Final Republican tax bill”. Reuters. 20 December. https://www.reuters.com/article/us-usa-tax-provisions-factbox/whats-in-the-final-republican-tax-bill-idUSKBN1ED27K; Price Waterhouse Cooper. 2017. "Tax Reform Legislation impact on Private Equity." https://www.pwc.com/us/en/services/tax/ library/insights/tax-reform-legislation-impact-on-private-equity.html.

Before considering more structural impacts we first discuss some short-term channels through which the TJA could affect investment flows into developing Asia and elsewhere as well as preliminary evidence.

\section{B. Incentives for Repatriation of Profits or Investment Back to the United States}

Initially there were concerns that the TJA could have reduced the supply of funds available for FDI as companies potentially repatriated as much as $\$ 2.5$ trillion in profits held overseas (UNCTAD 2018a). This foreign cash equivalent was created by an earlier rule making foreign profits tax-deferred if they are not brought into the US or repatriated. The concern was that countries where US cash holdings were high could suffer the most. For example, Ireland has a 12\% corporate tax and offered many benefits for high-tech firms. Before 2018, a US company would have to pay the US tax of $35 \%$, minus the $12 \%$ paid in Ireland before it could either invest the repatriated profits in the US or distribute as dividends to shareholders. Not surprisingly, American corporations decided to wait to repatriate those after-tax profits until after the passing of the TJA. Estimates noted that about a third of liquid profits ( $\$ 2.5$ trillion, equivalent to about $13 \%$ of US GDP in 2017) could be potentially repatriated out of a total of $\$ 6.4$ trillion 
held abroad (UNCTAD 2017). These existing assets would have had a transitory tax of $15.5 \%$ for cash levied under the TJA. Repatriations for reinvestment in US fixed capital would likely happen before 2022 to take advantage of the immediate depreciation provision.

Preliminary data on US foreign holdings suggest that the net impact of the TJA in the first few months after its implementation was visible but short-lived. While the reflow was noticeable by 2019, it was much smaller than earlier feared. A large part of these assets were held in offshore centers and their reflow back to the US through the residency of the owner was akin to a legal transaction with little or no impact on economic activity. Five recent trends in US equity investment abroad are evident:

(i) US foreign holdings of equity according to the US Treasury fell in 2018, but not enough to disturb the medium-term growth trend. Figure 6 shows the market value of US holdings of foreign equity, classified into equity investments in large offshore centers, developing Asia (including Singapore and Hong Kong, China which comprise about $12 \%$ of the total) and other economies. Total holdings rose by $28 \%$ in 2017 and then fell by $13 \%$ by end-2018, quite uniformly for all geographic areas. In other words, an increase of about 10\%, over the 2 years to 2018 on average, similar to the average annual growth rate since 2011. This suggests that part of the blip had as much to do with the rise in holdings in 2017 as it did with the fall in holdings in 2018. It is possible that US investors shifted assets out faster than normal in 2017 in anticipation of benefiting from the TJA and then repatriated at a lower rate in 2018.

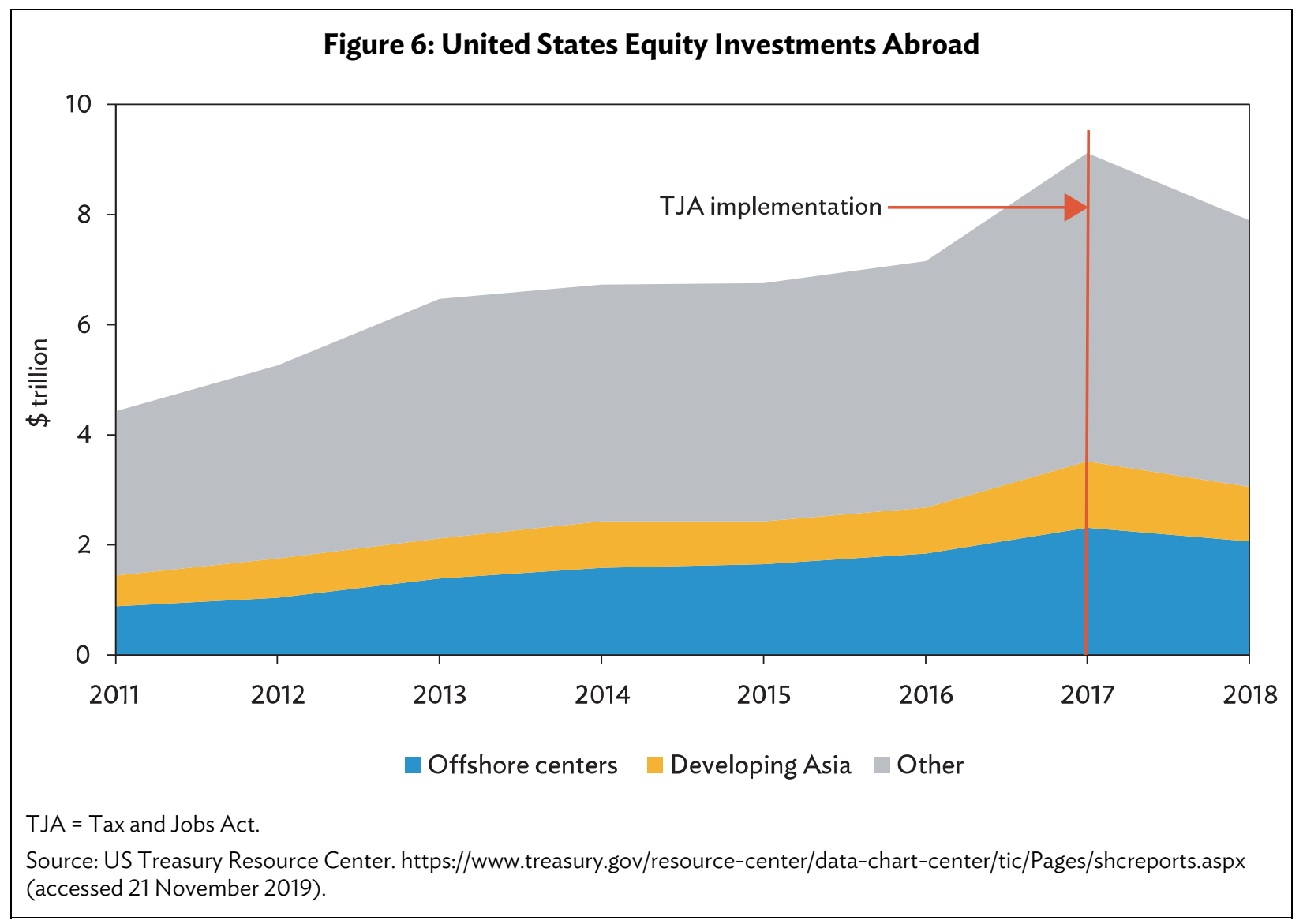


(ii) Data on direct investment flows from the balance of payments accounts also show an overall reduction in flow levels of outward FDI from the US. In the first half of 2018, flows of direct investment by US residents back to the US were very large, mostly related to nonbank holding companies and the wholesale trade sector (US Bureau of Economic Analysis). This coincides with the repatriation of profits from some of the giant US tech companies reported in the press (Apple and Amazon are classified as wholesale trade activities). In terms of geographic origin, the largest outflows came from Bermuda, the Netherlands, and Singapore in early 2018, and these outflows have mostly subsided. These jurisdictions have attractive incorporation rules for multinationals. There was also a very large inflow from US residents into Hong Kong, China in the first quarter of 2018 followed by outflows for the rest of the year.

(iii) In the second half of 2018 there was a small inflow back to the US, then in mid-2019 a small outflow, suggesting other channels were present. US FDI flows to developing Asia, which are dominated by those to Singapore and Hong Kong, China, have been falling steadily since the first quarter of 2018 until very recently when they have stabilized (US Bureau of Economic Analysis). The picture that emerges is that tax changes seems to have mostly impacted flows in early 2018 , but in 2019, the trade conflict and other uncertainties may have played a larger role on investor sentiment. However, it is important to note that this data does not distinguish between liquid flows, M\&A or funding of greenfield physical investment.

(iv) Repatriation of funds to use in plant and equipment was a theoretical possibility, but the evidence does not seem to support it so far. UNCTAD (2018b) hypothesized that one could see "reshoring of manufacturing activity" previously outsourced to low-wage countries, particularly if it is capital intensive (since capital expenditures on equipment are fully deductible until 2022 under the TJA). ${ }^{12}$ US gross fixed capital formation grew by 4.8\% in 2018 from 3.7\% in 2017, although in the second half of 2018 and into 2019, the growth rate fell. On an annual basis, it grew by $2.3 \%$ in 2019. It is possible that the 2018 growth was related to the TJA or other factors. Anecdotal reports noted that some large corporations were ready to expand factories following the TJA, but it is possible the plans were made in advance of the TJA passage, but investors waited until 2018 to repatriate funds to invest in the US..$^{3}$

(v) The OECD (2019) "FDI in Figures" report seems to corroborate this. It notes that although the immediate impact of the 2017 US tax reform lessened by 2019, reinvestment of earnings by US companies remained below levels recorded in the period 2013-2017, perhaps reflecting a "new normal" as US companies have less incentive to hold money at their foreign affiliates. Moreover, "the impact of these repatriations on the foreign operations of US [multinational enterprises] is likely to be minimal in the short term because they involve the sale or disposal of financial, as opposed to real, assets. The longer-term effects of the tax reform are more difficult to predict,

12 Japan and the PRC have also considered lowering the tax rate since the TJA was implemented. For the PRC, it included a reduced tax rate of $15 \%$ for high and new technology enterprises. The reduced tax rate of $15 \%$ is also applied to qualified technologically advanced service enterprises established in certain cities until 31 December 2018 (December 2017 for some cities). Also, enterprises operating in certain regions are eligible for a 15\% corporate tax rate until 31 December 2020. Moreover, effective tax rate of 10\% is granted to small-size and low-profit enterprises until 31 December 2017.

13 The shift to a territorial system under the TJA raised the incentive for foreign companies to invest in the US as well, particularly from the PRC (about 13\% of its inbound investment in 2013 went to the US, compared to 40\% for developing Asia). Property foreign investors with qualified real estate investment trust dividends, qualified cooperative dividends, and qualified publicly traded partnership income receive a $20 \%$ pass-through deduction. Overall, FDI from Asia to the US is likely to have increased as well to circumvent the tariffs on PRC products that began to be imposed in mid-2018. 
but US outward investment is likely to be lower going forward due to reduced reinvestment of earnings in foreign affiliates."

The above discussion provides an explanation of the impact of the TJA on FDI that is at best partial and at worst speculative. The next section thus sheds some light through our sector-level estimations.

\section{THE IMPACT OF THE TAXES DEPENDS ON THE SECTOR}

In this section, we consider the past relationship of US FDI by sector and estimate whether the host country's corporate tax rate-relative to the US corporate tax rate-had a statistically significant effect on the amount of US FDI to each country and sector, and if so, through what channel. We consider two hypotheses. The first hypothesis is that tax rates do not matter for FDI or only on the margin, once we control for other aspects such as availability of natural resources, market penetration, adequate infrastructure, investment climate, governance, etc. The second hypothesis is that taxes matter because the US corporate tax was so high relative to other countries pre-TJA that the marginal impact of lowering tax rates was substantial enough to free funds for new investment, most likely back to the US. Additionally, we consider whether the effect is different depending on the sector, and whether the impact is different for developing Asia compared to the full sample of 144 countries.

A panel fixed effects model is estimated with greenfield US outward FDI by sector and by country for the 2003-2017 period.

\section{A. Data Descriptions and Methodology}

This section describes in detail the data, model setup, and specifications and discusses the main findings from the analysis. As far as we know, this is the first attempt to estimate the dynamic relation between US firm-level outward investments FDI flows and the TJA.

1. Model Setup

We follow the model specification of Beck and Chaves (2011) and some aspects of ADB (2015), which is quite typical of most of the literature on cross-country determinants of FDI activity. The model specifications vary depending on the specific question (see Feld and Heckemeyer [2008] for an excellent literature survey). However, few cross-country studies consider the impact of changes in tax regimes.

Many studies have successfully adopted a gravity model to study the determinants of FDI using a Poisson quasi-maximum likelihood estimator. Since we are only interested in the motivation of US investors, so the "center of gravity" is only in one direction. As a result, many of the variable typical of gravity models (such as common language, colonial past, and common border) are eliminated in the estimation. Moreover, distance and transport costs important in trade gravity models may be less relevant for investment - if anything may lead to increased investment. Nonetheless, we included these variables in some estimations but found them to be not important or absorbed in the constant as part of the fixed effects, as expected. 
The model specification for the total economy or for any given sector is as follows:

$$
\begin{aligned}
\ln \text { US OFDI }_{i j t}= & c+\beta_{1} \ln \text { Market size }_{i t}+\beta_{2} \text { Institutions }_{i t}+\beta_{3} \ln \text { GDP }_{\text {growth }} \\
& +\beta_{4} \text { Business cycle }_{i t}+\beta_{5} \ln \text { Competitiveness }_{i t} \\
& +B_{6} \ln \text { Relative Costs }_{i t}+\beta_{7} \text { Tax differential }_{i t}+\beta_{8} Z_{i j t} \\
& +B_{9} \text { Country-Sector Dummy }_{i j}+B_{10} \text { Year Dummy }_{t}+e_{i j t}
\end{aligned}
$$

The subscripts $i, j$, and $t$, respectively represent country, sector, and time. Whereas, US OF $D_{i j t}$ is the total value of outward FDI of the US, by sector, to partner or destination country $i$. Institutions $s_{i t}$ is a measure of institutional quality; market size ${ }_{i t}$, indicates the market potential; GDP growth $h_{i t}$, the GDP growth of country $i$; business cycle $i t$, measures the stage of the business cycle of country $i$ around its average (potential) growth; competitiveness $s_{i t}$ measures country $i$ 's price or exchange rate competitiveness; and relative costs $s_{i t}$ measures the costs differential between the US and country $i$. Our variable of interest, tax differential ${ }_{i t}$, is the corporate tax rate differential between the US and country $i$ at time $t$. Finally, $Z_{i j t}$ is a vector of other control variables that potentially affects FDI flows, such as whether it has a double tax treaty with the US, investment climate, free trade arrangements, investment regulatory restrictions, degree of trade openness, distance, common language, etc. Most indicators, however, do not vary by sector. Finally, we have country-sector dummy for all but one of the 18 sectors, $j$. Year Dummy $y_{t}$ are year dummies from 2003 to $2016(t-1)$ to measure persistence, which include the period with a complete set of data; and $e_{i j t}$ is the error term.

In terms of the dependent variable, the literature takes various approaches. When there is data both on the number of projects and the dollar value of the investment (extensive margin), data on the number of projects is often used because it better captures the intention to invest or not, and it tends to be a more reliable indicator as it is easier to gauge whether the project is implemented or not. However, since we are interested in quantifying whether taxes are important, the amount of investment is crucial for calculating the semi-elasticity of FDI to the tax rate. Ideally, one would have a two-stage estimation, first using the number of projects as the dependent variable and then the dollar amount as the dependent variable conditional on whether there was investment. In our case, the first and second stage can be "merged" because the number of projects and amounts comes from the same dataset. However, it has the disadvantage that data for more recent years tends to be less accurate because it is based on the responses by surveyed firms, and in some cases the actual amounts for recent years can change slightly in the next survey year.

FDI data is from the fDi Markets service of Financial Times compiled by the Asian Economic Integration Report (see ADB [2015] appendix for details) and updated. Unlike direct foreign investment data recorded in the balance of payments, the database provides information on mode of entry, type of investment by sector, number of projects, destination country, and global ultimate ownership of the investment. This level of disaggregation is key to analyzing the actual amounts going to each sector and the effect of tax changes on the ultimate investor. We use greenfield investment, as opposed to M\&A, as we want to focus on investments that have more impact on economic activity (setting up of manufacturing facilities, new ventures, or any commercial physical investments established in a foreign country from scratch). The multicountry and multisector panel dataset covers 191 partner economies and annual data between 2003 and 2017 (37 of them in developing Asia). We aggregate the sector groupings into 18 according to the Standard International Trade Classification, and further, by investor motivation into four groups (see Table A.1). 


\section{Explanatory Variables}

We utilized a set of control variables based on identified motivations driving companies to undertake different types of FDI and some empirically tested drivers.

To capture the size of the market, we use population and GDP levels. Aziz and Makkawi (2012) find these indicators to be positive determinants of FDI inflows. The size of the consumer market can be proxied by the country's population, the size of its economy (GDP), or its labor force. As these variables are highly correlated with each other, they are interacted in the model. To analyze the role of institutions on FDI flows, we use institutional indicators from World Bank Worldwide Governance Indicators. ${ }^{14}$ Specifically, we use the composite indicator which aggregates six subindicators: voice and accountability, political stability, government effectiveness, regulatory quality, rule of law, and control of corruption. Investment climate, another institutional variable, also matter for the location decisions of foreign investors, thus, for robustness, we also used instead the World Bank's Ease of Doing Business Indicator.

Economic growth is an important determinant of aggregate FDI, and studies abound confirming that economic growth in the host or destination country are positively correlated with FDI inflows (see for example, Lamsiraroj and Doucouliagos [2015]).

Volatility in economic growth or business cycle fluctuations in the host or origin country also have significant impact on FDI outflows. Yeyati, Panizza, and Stein (2007) for instance, find that business cycles in advanced countries affect FDI flows into developing countries; and in fact, FDI is countercyclical during known cycles in the US and Europe, such as during the 1980s and 1990s. Following the market-seeking hypothesis, outward FDI may increase when foreign markets are in expansion, and FDI decline when they are in recession. Thus, to capture the likely relationship that US outward FDI is procyclical or countercyclical, we also looked into the difference between the US and the destination country $i^{\prime}$ s business cycle: Bscycle_d $d_{i t}^{U S}=$ Business $_{\text {Cycle }}$ Bt $_{i}-$ Business Cycle $_{U S t}$. Country $i$ 's business cycle is calculated as the ratio of the real GDP growth $y$ at time $t$ to the average real GDP growth $y$ over the past 10 years: $:^{15}$

$$
\text { Business Cycle } i t=\frac{y_{i t}}{\left(\frac{\sum_{k=t-9}^{t} y_{i k}}{10}\right)}
$$

Exchange rate data in destination countries are used as a short-term competitiveness indicator. The existing literature has been mixed on the relationship between FDI and exchange rates. We checked both real and real effective exchange rates to remove the likely impact of any form of government intervention, as in the case of managed floating exchange rate regimes.

Another measure to gauge the impact of changes in production costs is the producer price index in the destination country relative to the source country (US). Lower production costs could enhance manufacturing performance by firms, thus increasing incentives for foreign firms to invest.

We also include GDP per capita which likely summarizes a couple of effects. First, it is a correlate to the level of human capital or skill of workers which may be important for horizontal investors. Second, it is a proxy for the average real wages and thus the average costs of production in a country. Although

14 See World Bank. World Governance Indicators. https://info.worldbank.org/governance/wgi/ (accessed April 2019).

15 Since in our case, the difference will always be against the US's business cycle, the regression drops the second part of the expression. 
this is a somewhat crude summary statistic, it acts as an adequate control capturing this effect. We were not able to get a reliable time series for average wages of all countries and time periods, and even if we could, real wages can vary dramatically within countries and sectors.

Our variable of interest is the tax differential, which is calculated as the differential

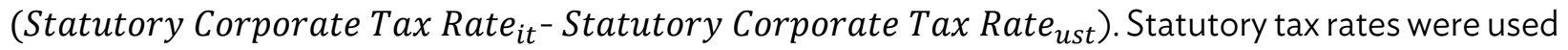
rather than actual past tax burdens following Devereux (2006) because of the forward-looking nature of investment decisions which are mostly based on future taxes triggered by the respective projects. Moreover, because of possible tax waivers and exemption, the statutory tax rate is likely larger than the average effective tax rate. However, as mentioned earlier, we find that the ordering of effective tax rates is broadly the same as the ordering of statutory tax rates (transitivity).

Other control variables include investment climate, regulatory restrictions and incentives, degree of trade openness, and "gravity-like" indicators. Barriers that impede participation by foreign firms can be: restrictions on the value of investment (such as equity limitations) or some measure which makes foreign investments more costly. We use the FDI index developed by OECD, which gauges the restrictiveness of a country's FDI rules by sector by looking at four main types of restrictions: foreign equity limitations; discriminatory screening or approval mechanisms; restrictions on the employment of foreigners as key personnel; and other operational restrictions such as on branching, capital repatriations, and land ownership by foreign-owned enterprises. The index is available at the sector level, an advantage, but is not available for many emerging countries, a disadvantage.

We sought to examine trade effects, but found few, if any, to be significant. For example, it would be important to determine the role of trading arrangements such as free trade arrangements (FTAs) and bilateral trade agreements or treaties between the US and host countries on US outward FDI flows. To analyze the impact of FTAs, we used the data compiled by Head, Mayer, and Ries (2010) which assigns a value of 1 if the host country has an FTA with the US, and 0 otherwise. On free trade zones (FTZs), we used the data constructed by Yücer, Siroën, and Archanskaia (2014), which counts the number of zones and provides other information such as the characteristics, location, year of implementation, size, fiscal regulation, and industrial specialization of each zone. To account for the size of the country's economy, we normalize the number of FTZs by per capita GDP. Ideally, we would want to know how much of the FDI is going to finance activities carried out in FTZs, but we could not find such data at the global level. To gauge the extent of a country's economic trade integration with the rest of the world, we used the standard proxy, the trade-to-GDP ratio. We also checked for other control variables such as doubletaxation treaties, as this may numb the impact of the tax rate in the receiving country; and tariff, a dummy variable equal to 1 if country $i$ is part of the Asia-Pacific Economic Cooperation or has a bilateral trade agreement with the US.

Time dummies as well as sector dummies were introduced, as well as interaction variables to check if the outcome depends on the state of a second causal variable. Sector fixed effects were also interacted with the statutory corporate tax rate to see if there was an effect of higher tax rates in certain sectors. Table 2 shows the variables used in the estimations and the summary statistics, including the dependent variable log of US FDI by sector. ${ }^{16}$ Only control variables that were significant are described here.

16 It should be noted that since we use the log of FDI, then investment of zero would be minus infinity and not tractable. At the same time, we wanted to preserve the basic relationship when taking logs, therefore, we made "zero" FDIs very small or assigned it an insignificant amount. We also ran the estimations taking the dependent variable without logs. The basic results did not change. 
Table 2: Description of Variables and Summary Statistics

\begin{tabular}{|c|c|c|c|c|c|c|c|}
\hline Effect to Estimate & Variable & Description & Obs & Mean & Std Dev & Min & Max \\
\hline $\begin{array}{l}\text { Dependent } \\
\text { Variable }\end{array}$ & $\ln c x$ & $\begin{array}{l}\text { Total US greenfield } \\
\text { investments to destination } \\
\text { country } i\end{array}$ & 9,720 & 7.050 & 8.815 & 0.000 & 23.759 \\
\hline Market size & Ingdppop_d & $\begin{array}{l}\text { Log of GDP x Population, } \\
\text { Destination country } i\end{array}$ & 9,720 & 15.147 & 2.719 & 9.479 & 23.443 \\
\hline Institutions & wgiave & $\begin{array}{l}\text { Standardized average } \\
\text { Worldwide Governance } \\
\text { Indicators, Destination } \\
\text { country } i \text { (lags included) }\end{array}$ & 9,720 & 3.157 & 0.851 & 1.173 & 4.394 \\
\hline Host growth & gdpgr_d & $\begin{array}{l}\text { Real GDP growth, } \\
\text { Destination country } i\end{array}$ & 9,720 & 2.588 & 3.730 & -14.800 & 25.557 \\
\hline Host growth & L1.gdpgr_d & $\begin{array}{l}\text { Lag1 of real GDP growth, } \\
\text { Destination country } i\end{array}$ & 9,720 & 2.818 & 3.719 & -14.800 & 18.287 \\
\hline Host growth & L2.gdpgr_d & $\begin{array}{l}\text { Lag2 of real GDP growth, } \\
\text { Destination country } i\end{array}$ & 8,874 & 2.881 & 3.837 & -14.800 & 18.287 \\
\hline Business cycle & bscycle_d & $\begin{array}{l}\text { Business cycle, calculated } \\
\text { as: Real GDP growth } h_{i t} / \\
10 \text { - year average growth }\end{array}$ & 9,720 & 0.942 & 3.105 & -18.058 & 38.545 \\
\hline FDI tax burden & taxdiff & $\begin{array}{l}\text { Tax differential, calculated } \\
\text { as: } \\
\text { Tax }_{\text {Destination country } i}- \\
\text { Tax }_{U S}\end{array}$ & 9,720 & 14.930 & 7.380 & -0.690 & 30.000 \\
\hline Openness & Inopen_d & $\begin{array}{l}\text { Log of merchandise trade } \\
\text { ( } \% \text { of GDP), Destination } \\
\text { country } i\end{array}$ & 9,702 & 4.144 & 0.522 & 2.845 & 5.845 \\
\hline $\begin{array}{l}\text { Real } \\
\text { competitiveness }\end{array}$ & Inreer_d & $\begin{array}{l}\text { Log of real effective } \\
\text { exchange rates, } \\
\text { Destination country } i\end{array}$ & 9,720 & 4.586 & 0.096 & 3.984 & 4.876 \\
\hline Relative costs & Inppi_d & $\begin{array}{l}\text { Log of producer price } \\
\text { index, Destination country } \\
i\end{array}$ & 9,720 & 4.597 & 0.164 & 3.594 & 5.279 \\
\hline Relative costs & ppidiff & $\begin{array}{l}\text { PPI differential, calculated } \\
\text { as: } \\
P P I_{\text {Destination country } i}- \\
P P I_{U S}\end{array}$ & 9,720 & 0.403 & 11.555 & -48.837 & 88.125 \\
\hline $\begin{array}{l}\text { Real } \\
\text { competitiveness }\end{array}$ & reerdiff & $\begin{array}{l}\text { REER differential, } \\
\text { calculated as: } \\
\text { REER } R_{\text {Destination country } i}- \\
R E E R_{U S}\end{array}$ & 9,720 & -4.485 & 11.307 & -55.520 & 22.120 \\
\hline $\begin{array}{l}\text { Real } \\
\text { competitiveness }\end{array}$ & Inrer_d & $\begin{array}{l}\text { Log of real exchange rate, } \\
\text { Destination country } i\end{array}$ & 7,056 & 4.624 & 0.232 & 3.609 & 6.154 \\
\hline $\begin{array}{l}\text { Additional control } \\
\text { for natural } \\
\text { resources }\end{array}$ & Incomprice & $\begin{array}{l}\text { Log of commodity price } \\
\text { index (energy), } \\
\text { Destination country } i\end{array}$ & 9,720 & 4.605 & 0.242 & 4.171 & 4.861 \\
\hline FDI restrictiveness & RRI_d & $\begin{array}{l}\text { FDI index, Destination } \\
\text { country } i\end{array}$ & 3,885 & 0.100 & 0.170 & 0.000 & 1.000 \\
\hline $\begin{array}{l}\text { Host human and } \\
\text { physical capacity }\end{array}$ & Inpcap & $\begin{array}{l}\text { Log of per capita income, } \\
\text { Destination country } i\end{array}$ & 9,720 & 9.674 & 1.082 & 6.541 & 11.521 \\
\hline
\end{tabular}

$\mathrm{FDI}$ = foreign direct investment, GDP = gross domestic product, $\mathrm{PPI}=$ producer price index, $\mathrm{REER}=$ real effective exchange rate, US = United States.

Note: FDI index is based on the OECD FDI regulatory restrictiveness index.

Source: Staff calculations. 


\section{B. Empirical Strategy}

We employ a panel approach to determine the impact of changes in US statutory corporate tax rates on US outward FDI flows. We used the country-sector fixed effects model. This technique was chosen over time series and cross section at the country level as it accounts for heterogeneity and autocorrelation. This is also confirmed by the Hausman Test, which assesses the appropriateness of a fixed effects or random-effects estimator based on properties of the data.

Fixed effects models are not without their drawbacks as there could easily be country-specific (groupwise) heteroskedasticity, multicollinearity issues, autocorrelation, and endogeneity between the dependent variable and explanatory variables. We used a battery of tests to correct for these possible problems. To address the issue of heteroskedasticity, which the results of the modified Wald Statistic for groupwise heteroskedasticity also confirmed, we applied clustering of standard errors across countries. This method also takes care of autocorrelation, although this is less of a concern given that our dataset has a dimension of $N>T$. To check for multicollinearity, we employed the variance inflation factor test which quantifies the extent of correlation between one variable and the other variables in a model. Results from the test confirmed that in most specifications, the variables are not collinear, but in cases where they are, variables are replaced, or are automatically removed since their effect would be captured in the constant as a country-specific effect. On possible endogeneity issues, our hypothesis, however, only requires that there is an association among the regressors and US FDI, not necessarily a direct causality. Even so, if there was endogeneity, it would require us to believe that as a result of US FDI, a country's aggregate macro variables would be significantly affected contemporaneously, which is unlikely given the small amounts of US FDI relative to the size of all economies considered. It is possible that negotiations over investment policies, FTA arrangements or tax rates in host countries could impact FDI, but all these variables are taken into account as control variables. The tax rate of the host country is subtracted from the regressor of interest. ${ }^{17}$ Moreover, by using the statutory tax rates to construct taxdiff as opposed to past average tax rates, we are avoiding the possibility that tax rate levels were impacted by past US FDI flows (see Devereux 2006). Finally, our approach to determine robustness was to choose the specifications that had both the highest mean square errors and relatively stable coefficient values and signs.

\section{Estimation Results for the Full Sample}

Table 3 shows the results for the full sample regressions specifications. ${ }^{18}$ The statistically significant coefficients are consistent with our expected signs: a smaller relative size of the host country market, proxied by the interaction of GDP and population, is negatively associated with US greenfield FDI. ${ }^{19}$ It is not always significant, though. The quality of institutions in the host country, proxied by the World Bank Worldwide Governance Indicators, is positively associated with higher US FDI. This result is quite robust and observed in the literature on the determinants of FDI. The proxy for institutional quality, the World Bank's Ease of Doing Business indicator, yielded similar results. With respect to short-term determinants, US FDI seems to be countercyclical: GDP growth above its 10-year trend is

17 Another approach would be to use Arellano and Bond (1991) difference generalized method of moments estimator first proposed by Holtz-Eakin et al. (1988). This model uses first differences of the dependent variable and a regressor to transform the regression in order to remove country fixed effects, and to make the regressors time invariant.

18 We tested at least 70 specifications to consider the effect of adding or subtracting different variables, but only a few are reported. Others are available from the authors upon request.

19 This result differs from Aziz and Makkawi (2012), but depends in part on our sample, and we did not have strong priors about its importance. In fact, it turns out to be mostly insignificant. 
associated with lower FDI. ${ }^{20} \mathrm{GDP}$ growth in the host country turns out to be positively associated with US FDI, and we show that many of the fast-growing countries targeted by US investors are in developing Asia. A more appreciated currency relative to the dollar in real terms and in real effective terms is associated with lower US FDI. Finally, we also lagged the GDP growth to reduce possible endogeneity, and in many cases, both the first and second lag are significant, reflecting persistence in the impact of GDP growth on US FDI.

In all specifications of the fixed effects model, the corporate tax differential-our variable of interest-was not significant and sometimes of the unexpected sign. This would be consistent with the James (2009) and Morisset and Pirnia (2001) hypothesis, namely: once other factors are considered, US foreign investors are not impacted by the relative corporate tax rate.

Other control variables were not as robust as expected. The log of producer price index (PPI) and the PPI differential with the US (not shown) were used as proxies for changes in cost differences, with the former variable not robust to specifications and the latter mostly insignificant. Moreover, in some cases when the PPI was included, the GDP per capita was no longer significant, suggesting that there could be some correlation between the wealth of the country and its relative prices (known as the Gerchenkron effect). It is difficult to interpret this at an aggregate country level. We substituted these with commodity prices to see if it was capturing this effect but found the commodity price coefficient insignificant. We also included the index of FDI regulatory restrictions which was rarely significant, probably because the indicator is only available for OECD countries-which significantly reduces the number of observations - so its effect may be already captured by per capita GDP. Trade openness was rarely significant and not robust in the full sample. Other variables such as FTZs, trade agreements, etc. were insignificant.

We also report the coefficients for specification 2 for the full sample with time dummies (Table 3, column 2B). The same specification with time dummies shows almost similar results except that the relative size of the host country market, business cycle, and per capita income are now insignificant, likely due to the impact of the global financial crisis in 2008 and large changes in commodity prices in 2015 on output and incomes.

20 We also tested the difference between destination and the US, subtracted from it the business cycle phases of the US to see if it worked; the business cycle was synchronized, but found that it is still countercyclical with respect to the host country, and thus, excluded. 


\section{Table 3: Regression Results (Fixed Effects Model), Full Sample}

Dependent variable: Log of greenfield investments

\begin{tabular}{|c|c|c|c|c|c|c|c|c|}
\hline Variable (Proxy for) & Description & (1) & $(2 \mathrm{~A})$ & $(2 \mathrm{~B})$ & (3) & (4) & (5) & (6) \\
\hline L.Ingdppop_d & $\begin{array}{l}\text { Log of GDP } x \\
\text { Population of }\end{array}$ & 0.377 & $-0.971^{* * *}$ & 0.770 & 0.372 & $-0.836^{* *}$ & -0.52 & -0.976 \\
\hline (market size) & $\begin{array}{l}\text { reporter/destination } \\
\text { country at time } t-1\end{array}$ & -0.543 & -0.339 & $(0.472)$ & -0.542 & -0.342 & -0.562 & -1.239 \\
\hline wgiave & $\begin{array}{c}\text { Standardized } \\
\text { average Worldwide }\end{array}$ & $1.718^{*}$ & $2.557^{* * *}$ & $2.324^{* * *}$ & $1.690^{*}$ & $2.211^{* * *}$ & $2.237^{* *}$ & 2.205 \\
\hline (business climate) & $\begin{array}{l}\text { Governance } \\
\text { Indicators }\end{array}$ & -0.908 & -0.639 & $(0.680)$ & -0.906 & -0.658 & -0.956 & -1.747 \\
\hline bscycle_d & Business cycle in & $-0.101^{* *}$ & $-0.0330^{* *}$ & -0.0203 & $-0.0950^{* *}$ & $-0.0294^{*}$ & $-0.107^{* *}$ & $-0.172^{* * *}$ \\
\hline (cyclical factors) & $\begin{array}{l}\text { reporter/destination } \\
\text { country }\end{array}$ & -0.0409 & -0.0163 & $(0.0166)$ & -0.0411 & -0.0163 & -0.0417 & -0.0591 \\
\hline \multirow{2}{*}{$\begin{array}{l}\text { gdpgr_d } \\
\text { (growth-seeking) }\end{array}$} & \multirow{2}{*}{$\begin{array}{l}\text { Real GDP growth of } \\
\text { reporter/destination } \\
\text { country }\end{array}$} & $0.0654^{* * *}$ & $0.0284^{*}$ & $0.0640^{* * *}$ & $0.0578^{* * *}$ & 0.0218 & $0.0491^{* *}$ & $0.302^{* * *}$ \\
\hline & & -0.0213 & -0.0163 & $(0.0185)$ & -0.0214 & -0.0165 & -0.0228 & -0.0599 \\
\hline Inpcap & $\begin{array}{c}\text { Log of GDP per } \\
\text { capita (current } \$ \text { ) of }\end{array}$ & -0.278 & $1.986^{* * *}$ & 0.313 & -0.298 & $1.874^{* * *}$ & 0.179 & 1.014 \\
\hline (host's wealth) & $\begin{array}{l}\text { reporter/destination } \\
\text { country }\end{array}$ & -0.774 & -0.615 & $(0.754)$ & -0.774 & -0.618 & -0.833 & -1.831 \\
\hline Inreer_d & $\begin{array}{l}\text { Log of real effective } \\
\text { exchange rate of }\end{array}$ & & $-2.182^{* *}$ & $-1.963^{* *}$ & & $-2.006^{* *}$ & & \\
\hline (competitiveness) & $\begin{array}{l}\text { reporter/destination } \\
\text { country }\end{array}$ & & -0.88 & $(0.968)$ & & -0.888 & & \\
\hline \multirow{2}{*}{$\begin{array}{l}\text { Inppi_d } \\
\text { (comparative } \\
\text { costs) }\end{array}$} & \multirow{2}{*}{$\begin{array}{l}\text { Log of producer price } \\
\text { index of reporter/ } \\
\text { destination country }\end{array}$} & 1.406 & & & $1.522^{*}$ & & $1.876^{* *}$ & 1.071 \\
\hline & & -0.861 & & & -0.864 & & -0.917 & -1.721 \\
\hline taxdiff & \multirow[b]{2}{*}{ Tax differential } & -0.0112 & -0.00709 & 0.0201 & -0.00725 & -0.0045 & -0.00393 & 0.00923 \\
\hline $\begin{array}{l}\text { (income tax } \\
\text { advantage) }\end{array}$ & & -0.0196 & -0.029 & $(0.0309)$ & -0.0198 & -0.0289 & -0.0219 & -0.0655 \\
\hline Inrer_d & Log of real exchange & $-1.194^{* *}$ & & & $-1.173^{* *}$ & & -0.88 & 1.829 \\
\hline (competitiveness) & $\begin{array}{l}\text { rate of reporter/ } \\
\text { destination country }\end{array}$ & -0.548 & & & -0.547 & & -0.579 & -1.118 \\
\hline \multirow[t]{2}{*}{ L.gdpgr_d } & \multirow{2}{*}{$\begin{array}{l}\text { Real GDP growth of } \\
\text { reporter/destination } \\
\text { country at time } t-1\end{array}$} & & & & $0.0326^{*}$ & $0.0415^{* * *}$ & & \\
\hline & & & & & -0.017 & -0.016 & & \\
\hline L2.gdpgr_d & $\begin{array}{l}\text { Real GDP growth of } \\
\text { reporter/destination } \\
\text { country at time } t-2\end{array}$ & & & & & & -0.0176 & $0.0453^{* *}$ \\
\hline RRI_d & FDI index: Reporter/ & & & & & & & -1.705 \\
\hline (restrictiveness) & Host countries & & & & & & & -2.859 \\
\hline \multirow[t]{2}{*}{ Constant } & & -2.386 & 3.545 & -6.190 & -2.836 & 2.741 & 1.46 & -6.345 \\
\hline & & -4.059 & -3.094 & $(4.057)$ & -4.06 & -3.105 & -4.434 & -9.615 \\
\hline Time fixed effects & & No & No & Yes & No & No & No & No \\
\hline $\begin{array}{l}\text { Country-sector } \\
\text { fixed effects }\end{array}$ & & Yes & Yes & Yes & Yes & Yes & Yes & Yes \\
\hline Observations & & 9,900 & 12,762 & 12,762 & 9,900 & 12,762 & 9,018 & 3,330 \\
\hline R-squared & & 0.004 & 0.004 & 0.008 & 0.004 & 0.005 & 0.004 & 0.011 \\
\hline Number of id & & 1,026 & 1,296 & 1,296 & 1,026 & 1,296 & 1,026 & 540 \\
\hline
\end{tabular}

$\mathrm{FDI}=$ foreign direct investment, GDP = gross domestic product.

Notes: Joint tests were performed to see if the year dummies for all years are equal to 0 . Some specifications failed to reject the null, thus, no time fixed effects are needed, while it is significantly rejected in others. For this table, more results for specifications with no time fixed effects were shown, emphasizing more on the impact of business cycles. FDI index is based on the OECD FDI regulatory restrictiveness index. Robust standard errors in parentheses. ${ }^{* *} p<0.01,{ }^{* *} p<0.05,{ }^{*} p<0.1$.

Source: Staff calculations. 
The variables most associated with US FDI vary depending on whether the economy is in developing Asia or not, likely suggesting that the motives vary somewhat. Given that an Asia dummy was significant in the full sample, Table 4 shows results of splitting the sample into two groups: economies inside developing Asia and countries outside. We show the best specification for each subsample, as well as a common specification (Equations [1] and [6] of Table 4), both with and without time dummies. The importance of some coefficients over others is noteworthy: For Asia the economy's growth and excess capacity over the business cycle, as well as relative competitiveness seem to matter. Interestingly, neither the size of the host market (Ingdppop), the institutional quality or the wealth and capital levels matter for Asia, variables which are all statistically significant for the non-Asia sample. This is somewhat consistent with the large amount of FDI that goes into GVC-related activities in Asia. ${ }^{21}$ The production cost changes (proxied by the In_ppi_d variable) is positive instead of negative in the Asia equation. As in the full sample, taxdiff is not significant and sometimes has the opposite sign. In non-Asian countries, the relatively appreciated exchange rate in effective terms is important. When time dummies are included, both subsamples show 2008 to be positively significant, suggesting many firms took advantage of low costs during the global financial crisis to install capital. The cyclical variable also tends to lose significance once time dummies are included, as expected.

\section{Table 4: Regression Results (Fixed Effects Model), Developing Asia versus Nondeveloping Asia}

Dependent variable: Log of greenfield investments

\begin{tabular}{|c|c|c|c|c|c|c|c|c|}
\hline \multirow[b]{2}{*}{ Variable (Proxy for) } & \multicolumn{4}{|c|}{ Developing Asia } & \multicolumn{4}{|c|}{ Nondeveloping Asia } \\
\hline & $(1)^{a}$ & (2) & (3) & $(4)^{b}$ & (5) & $(6)^{a}$ & (7) & $(8)^{b}$ \\
\hline L.Ingdppop_d & 0.953 & -1.163 & $3.885^{*}$ & $\begin{array}{l}-1.701 \\
\end{array}$ & $-1.153^{*}$ & -0.782 & $-1.107^{*}$ & 0.726 \\
\hline (market size) & $(1.409)$ & $(0.885)$ & (2.134) & $(1.314)$ & $(0.655)$ & $(0.545)$ & $(0.655)$ & (0.531) \\
\hline wgiave & 2.477 & -0.00295 & 2.510 & 1.544 & $2.750^{* *}$ & $2.290^{* * *}$ & $2.642^{* *}$ & $2.783^{* * *}$ \\
\hline (business climate) & $(1.969)$ & $(0.816)$ & $(2.057)$ & (1.363) & (1.074) & $(0.879)$ & (1.081) & $(0.865)$ \\
\hline bscycle_d & $-1.580^{* *}$ & $-0.361^{* *}$ & -0.947 & -0.187 & -0.0245 & $-0.0285^{*}$ & -0.0234 & -0.0203 \\
\hline (cyclical factors) & $(0.629)$ & $(0.144)$ & $(0.745)$ & $(0.136)$ & $(0.0169)$ & $(0.0169)$ & $(0.0169)$ & $(0.0167)$ \\
\hline gdpgr_d & $0.258^{* * *}$ & $0.0680^{* *}$ & $0.276^{* * *}$ & $0.0642^{*}$ & $0.0410^{*}$ & $0.0425^{* *}$ & 0.0379 & $0.0600^{* * *}$ \\
\hline (growth-seeking) & $(0.0954)$ & $(0.0337)$ & $(0.102)$ & $(0.0386)$ & $(0.0241)$ & -0.019 & $(0.0241)$ & $(0.0223)$ \\
\hline Inpcap & -1.092 & 1.193 & $-4.147^{*}$ & -0.0300 & $3.134^{* * *}$ & $1.444^{* *}$ & $2.943^{* * *}$ & 0.587 \\
\hline (host's wealth) & $(2.126)$ & (1.392) & $(2.451)$ & (1.908) & $(0.981)$ & $(0.614)$ & (1.004) & $(0.852)$ \\
\hline Inreer_d & & 0.611 & & 3.267 & $-3.009^{* *}$ & & $-2.757^{* *}$ & $-2.551^{* *}$ \\
\hline (competitiveness) & & (2.317) & & $(2.812)$ & $(1.274)$ & & $(1.313)$ & $(1.052)$ \\
\hline Inppi_d & $2.814^{*}$ & & 2.874 & & -0.807 & -0.281 & -0.605 & \\
\hline (comparative costs) & $(1.579)$ & & $(2.159)$ & & $(0.753)$ & $(0.639)$ & $(0.779)$ & \\
\hline taxdiff & -0.0627 & 0.0826 & 0.0167 & 0.0593 & 0.000859 & 0.0220 & 0.00338 & 0.0231 \\
\hline $\begin{array}{l}\text { (income tax } \\
\text { advantage) }\end{array}$ & $(0.0741)$ & $(0.0553)$ & $(0.0764)$ & $(0.0753)$ & $(0.0353)$ & $(0.0189)$ & $(0.0353)$ & $(0.0347)$ \\
\hline L.gdpgr_d & & & & & & & 0.0261 & \\
\hline & & & & & & & $(0.0215)$ & \\
\hline
\end{tabular}

21 We also ran the developing Asia subsample excluding the PRC to ensure that the results were not affected by its large size; and also excluded Kazakhstan to ensure the large hydrocarbon investments there did not dominate. The coefficients obtained were very similar with or without these countries. 


\begin{tabular}{|c|c|c|c|c|c|c|c|c|}
\hline \multirow[b]{2}{*}{ Variable (Proxy for) } & \multicolumn{4}{|c|}{ Developing Asia } & \multicolumn{4}{|c|}{ Nondeveloping Asia } \\
\hline & $(1)^{a}$ & (2) & (3) & $(4)^{b}$ & (5) & $(6)^{a}$ & (7) & $(8)^{b}$ \\
\hline Inrer_d & & & -2.132 & & & & & \\
\hline (competitiveness) & & & $(1.584)$ & & & & & \\
\hline \multirow[t]{2}{*}{ Constant } & -3.704 & 7.438 & -29.07 & 7.627 & 2.082 & -2.445 & 1.440 & -7.236 \\
\hline & $(7.890)$ & $(6.128)$ & $(22.72)$ & $(9.422)$ & $(5.402)$ & $(4.403)$ & $(5.400)$ & $(4.787)$ \\
\hline Time fixed effects & No & No & Yes & Yes & No & No & No & Yes \\
\hline $\begin{array}{l}\text { Country-sector fixed } \\
\text { effects }\end{array}$ & Yes & Yes & Yes & Yes & Yes & Yes & Yes & Yes \\
\hline Observations & 2,232 & 1,818 & 2,232 & 1,818 & 8,586 & 10,854 & 8,586 & 10,944 \\
\hline R-squared & 0.010 & 0.003 & 0.027 & 0.020 & 0.007 & 0.004 & 0.007 & 0.009 \\
\hline Number of id & 234 & 180 & 234 & 180 & 828 & 1,062 & 828 & 1,116 \\
\hline \multicolumn{9}{|c|}{ a Common specifications, without year dummies. ${ }^{b}$ Common specifications with year dummies. } \\
\hline \multicolumn{9}{|c|}{$\begin{array}{l}\text { Notes: Joint tests were performed to see if the year dummies for all years are equal to } 0 \text {. Some specifications failed to reject the null, thus, } \\
\text { no time fixed effects are needed, while it is significantly rejected in others. Robust standard errors in parentheses. }{ }^{* *} p<0.01 \text {, } \\
{ }^{* *} p<0.05,{ }^{*} p<0.1 \text {. }\end{array}$} \\
\hline \multicolumn{9}{|l|}{ Source: Staff calculations. } \\
\hline
\end{tabular}

\section{Estimation Results by Sectors}

While we expect some of these variables to be important regardless of the sector, we also investigated what differences there may be across the 18 sectors. When we included sector dummies in the main regressions in Table 3, with few exceptions, they were significant, indicating that US greenfield FDI responds favorably to sector-specific characteristics as well.

We also included specifications where the sector dummy is interacted with the taxdiff variable, instead of including the taxdiff on its own. This would help indicate whether a higher corporate tax rate conditional on investing in the sector can augment or deter US FDI.

We ran the same regression specifications at the sector level, which provides specific information about what matters and what doesn't for investors interested in that sector. One word of caution is that the amount of investment is quite small in some cases (or include many "zeros" implying that the US does not have much FDI in those sectors). The procedure was to examine the coefficients of the control variables across specifications and see whether their value, sign, and significance stayed roughly stable. Table A. 2 in the appendix summarizes all the results. If there is a blank in an entry, it was because it was neither significant nor robust. The cell summarizes the most common result. Only a few variables come out as significant. Not surprisingly, sectors where US FDI is large tend to have a few variables explain most of the effect.

Finally, to try to get a better sense of how a type of sector affects the US investor's motivation, we aggregate the 18 sectors into four sectors, which we label as follows:

A. GVC-efficiency related. Refers to the sectors that have high GVC participation and in which the production process is fragmented internationally. Investors in these sectors tend to target low cost and efficiency in the host country and typically import for exporting. This is sometimes also referred to as vertical FDI. 
B. Large host market seeking. Sectors in which FDI is seeking a large market in the host country, in which US investors may be interested in establishing a commercial presence in the country to cater to local demand. These are mostly horizontal investors.

C. Sectors for resource-seeking investors, such as foreign investment in oil and gas, real estate or tourism, and recreation, among others. These could be both horizontal or vertical, but their primary motivation pertains to exploiting a resource found in abundance in the host country.

D. Sectors in which US investment is minimal or did not fit neatly into one of these categories is grouped into "other."

Table 5 shows the shares and Table A.1 details the chosen grouping.

\section{Table 5: Share of United States Greenfield Outward Foreign Direct Investment, 2003-2017}

\begin{tabular}{lcc}
\hline & Total & To Developing Asia \\
\hline GVC-efficiency related & $55.0 \%$ & $52.2 \%$ \\
Large market seeking & $17.5 \%$ & $15.2 \%$ \\
Location specific, resource seeking & $27.1 \%$ & $32.2 \%$ \\
Other & $0.4 \%$ & $0.4 \%$ \\
Total & $100.0 \%$ & $100.0 \%$ \\
\hline GVC = global value chain. & & \\
Source: Staff calculations using data from fDi Markets. https:/www.fdimarkets.com (accessed April 2019).
\end{tabular}

We ran all the specifications separately for each of the four groupings to investigate whether corporate taxes may be important for some of these groupings in the aggregate. Table 6 presents the results for the best specification of each sector grouping. There is an important improvement in the fit of the regressions.

The first thing to note is that the coefficient on taxdiff related to the effect of corporate tax differentials is still not significant, and in fact negative for market-seeking FDI. Moreover, some of the determinants matter more depending on the motivation. For example, GVC-efficiency seeking investors are more sensitive to the business climate, as well as the growth (both contemporaneous and lagged) of the host economy and whether the country is in an expansionary phase of the business cycle. Not surprisingly, the trade openness of the economy for FDI in these sectors is important. Moreover, comparative costs may be higher reflecting quality (which tends to be the case for hi-tech manufacturing).

In terms of resource or location-seeking FDI, the size of the economies as reflected in the insignificant coefficient of Ingdppop is not important, but the quality of institutions also matter, likely reflecting the importance of a stable regime for resource extraction or hospitality investments. The negative coefficient of per capita GDP suggests US foreign investors in these sectors are going to few wealthy countries, on average.

For FDI seeking large host markets, the most important variable is the size of the market, presumably because this is where there is greater opportunity for demand growth. Moreover, unlike the GVC-efficiency seeking investors, these investors want the local currency exchange rate and costs to be cheap relative to the US. For the regressions of "other" sectors, country-specific effects are somewhat important but dominated by the wealth of the country. 
Table 6: Regression Results (Fixed Effects Model), Full Sample by Sector Motivation Groups

Dependent variable: US greenfield FDI

\begin{tabular}{|c|c|c|c|c|c|}
\hline Variable (Proxy for) & Description & $\begin{array}{c}\text { GVC-Efficiency } \\
\text { Specific }\end{array}$ & $\begin{array}{l}\text { Location } \\
\text { Specific }\end{array}$ & Market Share & Other \\
\hline $\begin{array}{l}\text { L.Ingdppop_d } \\
\text { (market size) }\end{array}$ & $\begin{array}{l}\text { Log of GDP } \times \text { Population } \\
\text { of reporter/destination } \\
\text { country at time t-1 }\end{array}$ & $\begin{array}{r}0.590 \\
(1.107)\end{array}$ & $\begin{array}{l}0.998 \\
-1.172\end{array}$ & $\begin{array}{l}2.614^{*} \\
(1.441)\end{array}$ & $\begin{array}{r}-0.0503 \\
(0.672)\end{array}$ \\
\hline $\begin{array}{l}\text { wgiave } \\
\text { (business climate) }\end{array}$ & $\begin{array}{c}\text { Standardized average } \\
\text { Worldwide Governance } \\
\text { Indicators }\end{array}$ & $\begin{array}{l}3.283^{* *} \\
(1.604)\end{array}$ & $\begin{array}{l}3.302^{*} \\
(1.695)\end{array}$ & $\begin{array}{r}1.721 \\
(1.775)\end{array}$ & $\begin{array}{r}0.366 \\
(1.336)\end{array}$ \\
\hline $\begin{array}{l}\text { bscycle_d } \\
\text { (cyclical factors) }\end{array}$ & $\begin{array}{l}\text { Business cycle in } \\
\text { reporter/destination } \\
\text { country }\end{array}$ & $\begin{array}{l}-0.156^{* *} \\
(0.0705)\end{array}$ & $\begin{array}{r}0.0201 \\
(0.0261)\end{array}$ & $\begin{array}{r}0.0178 \\
(0.0319)\end{array}$ & $\begin{array}{l}-0.0154 \\
(0.0386)\end{array}$ \\
\hline $\begin{array}{l}\text { gdpgr_d } \\
\text { (growth-seeking) }\end{array}$ & $\begin{array}{l}\text { Real GDP growth of } \\
\text { reporter/destination } \\
\text { country }\end{array}$ & $\begin{array}{l}0.118^{* * *} \\
(0.0450)\end{array}$ & $\begin{array}{c}0.104^{* *} \\
(0.0409)\end{array}$ & $\begin{array}{r}0.0433 \\
(0.0480)\end{array}$ & $\begin{array}{l}-0.0223 \\
(0.0281)\end{array}$ \\
\hline $\begin{array}{l}\text { Inpcap } \\
\text { (host's wealth) }\end{array}$ & $\begin{array}{l}\text { Log of GDP per cap } \\
\text { (current \$) of reporter/ } \\
\text { destination country }\end{array}$ & $\begin{array}{l}-0.730 \\
(1.558)\end{array}$ & $\begin{array}{l}-2.816^{*} \\
(1.577)\end{array}$ & $\begin{array}{r}1.918 \\
(2.328)\end{array}$ & $\begin{array}{l}1.924^{* *} \\
(0.819)\end{array}$ \\
\hline $\begin{array}{l}\text { Inreer_d } \\
\text { (competitiveness) }\end{array}$ & $\begin{array}{l}\text { Log of real effective } \\
\text { exchange rate of } \\
\text { reporter/destination } \\
\text { country }\end{array}$ & & & $\begin{array}{r}-5.847^{* *} \\
(2.535)\end{array}$ & \\
\hline $\begin{array}{l}\text { Inppi_d } \\
\text { (comparative costs) }\end{array}$ & $\begin{array}{l}\text { Log of producer price } \\
\text { index of reporter/ } \\
\text { destination country }\end{array}$ & $\begin{array}{l}4.113^{* *} \\
(1.828)\end{array}$ & $\begin{array}{l}-0.268 \\
(1.400)\end{array}$ & $\begin{array}{l}-0.590 \\
(1.120)\end{array}$ & $\begin{array}{l}-1.448^{* *} \\
(0.654)\end{array}$ \\
\hline $\begin{array}{l}\text { taxdiff } \\
\text { (income tax advantage) }\end{array}$ & Tax differential & $\begin{array}{r}0.0437 \\
(0.0333)\end{array}$ & $\begin{array}{l}0.00270 \\
(0.0392)\end{array}$ & $\begin{array}{r}-5.09 e-06 \\
(0.0636)\end{array}$ & $\begin{array}{r}0.0319 \\
(0.0269)\end{array}$ \\
\hline $\begin{array}{l}\text { Inrer_d } \\
\text { (competitiveness) }\end{array}$ & $\begin{array}{c}\text { Log of real exchange rate } \\
\text { of reporter/destination } \\
\text { country }\end{array}$ & $\begin{array}{l}-1.227 \\
(1.044)\end{array}$ & & & \\
\hline $\begin{array}{l}\text { L2.gdpgr_d } \\
\text { (growth-seeking) }\end{array}$ & $\begin{array}{l}\text { Real GDP growth of } \\
\text { reporter/destination } \\
\text { country at time t- } 2\end{array}$ & $\begin{array}{l}0.0791^{* *} \\
(0.0330)\end{array}$ & & & \\
\hline $\begin{array}{l}\text { Inopen_d } \\
\text { (trade openness) }\end{array}$ & $\begin{array}{l}\text { Log of total trade as share } \\
\text { of total GDP of reporter/ } \\
\text { destination country }\end{array}$ & $\begin{array}{l}2.255^{*} \\
(1.210)\end{array}$ & & & \\
\hline Constant & & $\begin{array}{r}-24.92^{* *} \\
(11.53)\end{array}$ & $\begin{array}{r}6.479 \\
(12.82)\end{array}$ & $\begin{array}{r}-26.96^{* *} \\
(11.81)\end{array}$ & $\begin{array}{l}-11.21^{* *} \\
(5.473)\end{array}$ \\
\hline Time fixed effects & & No & Yes & Yes & No \\
\hline $\begin{array}{l}\text { Country-sector fixed } \\
\text { effects }\end{array}$ & & Yes & Yes & Yes & Yes \\
\hline Observations & & 3,000 & 2,908 & 3,240 & 1,454 \\
\hline R-squared & & 0.014 & 0.028 & 0.016 & 0.012 \\
\hline Number of id & & 342 & 288 & 318 & 144 \\
\hline
\end{tabular}

$\mathrm{FDI}=$ foreign direct investment, GDP = gross domestic product, GVC = global value chain, US = United States.

Notes: Joint tests were performed to see if the year dummies for all years are equal to 0 . Results show mixed F-values for motivation groups "GVC-efficiency specific," "location," and "market share," indicating that some specifications failed to reject the null, thus, no time fixed effects are needed. Meanwhile, all specifications for "others" do not require time fixed effects. Robust standard errors in parentheses. ${ }^{* *} p<0.01,{ }^{* *} p<0.05,{ }^{*} p<0.1$.

Source: Staff calculations. 
The results in Table 6 confirm the hypothesis that investors care about a host of other things and not the tax rate. Indeed, in a few cases, the coefficient on taxdiff comes out slightly significant, but negative. This is also something found by Bénassy-Quéré, Gobalraja, and Trannoy (2007): a host country slashing corporate taxes may create a bad signal for long-term investors because it means the government will not be able to raise the revenues to keep a basic quality of physical infrastructure and human capital that is necessary for a healthy investment environment. This is also corroborated by the high significance of the institutional variables and the GDP per capita in most regressions.

\section{E. Possible Impact on Some Sectors}

Despite this overall result, we investigate further the argument posed by Hines (2017) in which some highly taxed sectors may be particularly sensitive to the tax rate. Our results at the 18-sector level did find that agriculture and natural resources seems to be impacted by it, although not always. ${ }^{22}$ For clothing and footwear, there is a small sensitivity but US FDI in this sector is miniscule. For transport services, it is interpreted as a margin given that in the equation, the taxdiff variable is highly correlated to the cost differential variable ppi_diff. Taxdiff turns out to be significant for FDI in the real estate activities sector and wholesale trade, but negative, although in a few specifications. This implies investors are more worried about a high relative tax in the host economy than in the US. ${ }^{23}$ For financial intermediation, we also created a dummy for offshore centers to isolate as much as possible the presence of empty corporate shells transferring funds or other offshore activities. Even excluding the broadest definition of offshore centers from the equation, the coefficient on taxdiff is sometimes significant. ${ }^{24}$ Financial intermediation and business services-about 16\% of US FDI to developing Asia-are sensitive to tax changes. Taxdiff is significant in about half of the specifications of FDI in business services. This makes some sense, as by nature, this type of investment is more flexible: those US investors who provide business services are more mobile and can move from jurisdiction to jurisdiction.

Taking a conservative approach, the impact of the tax differential is still small. We estimate the semi-elasticity of the corporate tax rate with respect to US FDI and then weigh each sector's FDI by its share in total and only taking sectors where the coefficient of taxdiff was statistically significant (Table 7). For the sectors where taxdiff is significant, the coefficient is 1.63 on average. In other words, a 1 percentage point drop in the US corporate tax rate relative to other countries will increase FDI by $1.63 \%$, all else equal, for the six sectors for which the coefficient is significant. We simulate a decline in taxdiff by 14 percentage points (as US tax rate fell from roughly $35 \%$ to $21 \%$ ) to forecast and extrapolate the results. Under this scenario, the tax reform will reduce total FDI by almost 0.6 percentage points relative to 2017 (for developing Asia it's 0.72). If one considers that the average change from year to year of all US FDI abroad was 23\% in absolute terms (mostly growth), then the tax impact seems relatively unimportant.

22 In general, the results of this sector's regression are poor and not stable. We experimented by removing Kazakhstan from the sample (given a large US investment in 2017) and adding the commodity price index and an Organization of the Petroleum Exporting Countries dummy. None of these variables were significant. Although the PPI was somewhat correlated to taxdiff, FDI to this sector is highly volatile so we do not put much weight on the results for this sector.

23 The corollary is that real estate foreign investment from elsewhere into the US is likely to receive an important incentive.

24 A highly conservative definition was to assume that all US FDI in financial intermediaries to Hong Kong, China; Ireland; Switzerland; the Netherlands; and Luxembourg (about 9\% of total US FDI into financial intermediation) was offshore activity likely to be seeking tax shelters. 


\section{Table 7: Semi-elasticity and Projections on Foreign Direct Investment of a Change in United States Corporate Tax Rate from $36 \%$ to $21 \%$}

\begin{tabular}{lccc}
\hline Sector & $\begin{array}{c}\text { Income Tax-FDI } \\
\text { Semi-elasticities }\end{array}$ & $\begin{array}{c}\text { Sector Shares in } \\
\text { Total FDI, 2017 }\end{array}$ & $\begin{array}{c}\text { Developing Asia Sector } \\
\text { Share in Total Developing } \\
\text { Asia FDI, 2017 }\end{array}$ \\
\hline $\begin{array}{l}\text { Agriculture, natural resources, } \\
\text { mining and quarrying }\end{array}$ & 0.133 & $10.5 \%$ & $15.8 \%$ \\
Clothing and footwear & 0.0576 & $0.0 \%$ & $0.0 \%$ \\
Wholesale and retail trade & -0.11 & $3.9 \%$ & $3.4 \%$ \\
Transport services & 0.12 & $5.3 \%$ & $7.3 \%$ \\
Financial Intermediation & 0.144 & $6.1 \%$ & $6.3 \%$ \\
Renting of machines and & 0.193 & $9.2 \%$ & $9.8 \%$ \\
equipment, and other business & & & \\
activities & & $35.0 \%$ & $43.0 \%$ \\
Sum & 1.68 & $4.3 \%$ & $5.4 \%$ \\
Effective semi-elasticity and & & 0.59 & 0.72 \\
contributions & & & \\
Projected percent increase in FDI & & & \\
\hline
\end{tabular}

$\mathrm{FDI}=$ foreign direct investment.

Source: Staff calculations.

Part of the reason why we do not obtain the sensitivity to the tax rate at the order of magnitude discussed by Hines (2017) is likely because we are using firm-level data on greenfield investment, which is likely to represent flows for production and not strategic, liquid flows such as profit repatriations of hi-tech companies or mergers and acquisitions, or movements to and from offshore centers that are highly sensitive to tax changes.

\section{CONCLUSIONS AND POLICY RECOMMENDATIONS}

This paper assesses whether the 2017 US TJA, which significantly lowered the US corporate tax rate, could have impacted the amount of US greenfield FDI abroad, particularly to developing Asia. The novelty of our approach is to take advantage of the rich sector-level data to classify FDI into sectorbased groups that best capture the motivation of foreign investors discussed in the literature. The results suggest that, excepting some sectors where funding of the activity tends to be more liquid, changes in the tax rate do not significantly affect US FDI decisions, but instead, other factors such as the quality of institutions, wealth and exchange rate competitiveness are more important. Even taking the most extreme interpretation of our results, the TJA shaved at most 0.6 percentage points off US FDI globally (0.72 off US FDI to developing Asia).

There are many forces at work in the decisions of investors to locate in a country or region, and developing Asia continues to be an attractive region based on the growth of its consumer market, production linkages, and constant improvements in the business environment. Policy makers in developing Asia should therefore not take the attitude that lowering their taxes will attract more investments from the US, but instead, use available resources to improve their human and physical 
capital to raise their growth potential. Our estimate suggests that, at best, taxes matter only on the margin. It would not be advisable for policy makers to dab with the tax system to react to the recent changes in the US, but instead, use revenues efficiently to improve human and physical capital.

Since the TJA, the US-PRC trade conflict, which escalated into an investment conflict as well throughout 2019, has dominated the international arena. While it complicates the isolation of effects due solely to the TJA, it does provide important lessons about the ability of tax and tariff changes to have an impact on investment decisions. The uncertainty that was created from the escalation is what has deterred investors the most, not necessarily the size of the tariffs (although the tariff has led to trade redirection of intermediate goods). Moreover, FDI has declined in the two protagonist countries-the US and the PRC - but has actually increased in some economies in developing Asia that have benefited from the redirection (ADB 2019a). More importantly, the US has not seen the surge in investment many projected would come as repatriated funds were invested domestically, despite some short-lived profit repatriation in the first half of 2018. In fact, gross fixed capital formation as a share of GDP declined slightly in 2019. Moreover, at the time of publishing, US FDI position in developing Asia was higher at end-2019 ( $\$ 823.6$ billion) compared to end-2017 ( $\$ 821.5$ billion), despite falling slightly in 2018 , suggesting appetite for investment abroad reverted quickly. 


\section{APPENDIX}

\section{Table A.1: Classification of Sectors by Motivation Factor}

\begin{tabular}{|c|c|c|c|}
\hline Sector & Type of Activity & $\begin{array}{c}\text { Share of Sector } \\
\text { in Total US } \\
\text { Greenfield FDI } \\
\text { into Developing } \\
\text { Asia }\end{array}$ & FDI Entry Motivation \\
\hline $\begin{array}{l}\text { Agriculture, natural resources, mining and } \\
\text { quarrying }\end{array}$ & Resource extraction & $15.8 \%$ & $\begin{array}{l}\text { Location specific, resource } \\
\text { seeking }\end{array}$ \\
\hline $\begin{array}{l}\text { Machinery, transport equipment and sale } \\
\text { and maintenance of motor vehicles and } \\
\text { manufacturing, nes }\end{array}$ & Hi-tech manufacturing & $14.3 \%$ & GVC-efficiency related \\
\hline $\begin{array}{l}\text { Renting of machinery and equipment and } \\
\text { other business activities }\end{array}$ & Service trade & $9.8 \%$ & GVC-efficiency related \\
\hline Petrochemicals, refining, rubber and plastics. & Hi-tech manufacturing & $9.5 \%$ & GVC-efficiency related \\
\hline Tourism, hotels, restaurants & Nontradable & $7.6 \%$ & $\begin{array}{l}\text { Location specific, resource } \\
\text { seeking }\end{array}$ \\
\hline Transport services & Infrastructure & $7.3 \%$ & GVC-efficiency related \\
\hline Electrical and optical equipment & Hi-tech manufacturing & $6.7 \%$ & GVC-efficiency related \\
\hline Financial intermediation & Offshore & $6.3 \%$ & Large market seeking \\
\hline Post and telecommunications & Infrastructure & $4.6 \%$ & GVC-efficiency related \\
\hline Real estate activities & Service trade & $4.0 \%$ & $\begin{array}{l}\text { Location specific, resource } \\
\text { seeking }\end{array}$ \\
\hline Wholesale and retail trade & Nontradable & $3.4 \%$ & Large market seeking \\
\hline Metals and nonmetallic minerals & Hi-tech manufacturing & $3.0 \%$ & $\begin{array}{l}\text { Location specific, resource } \\
\text { seeking }\end{array}$ \\
\hline Food, beverages and tobacco & Basic manufacturing & $3.0 \%$ & Large market seeking \\
\hline Electricity, gas and water supply & Infrastructure & $2.2 \%$ & Large market seeking \\
\hline Wood and paper products & Basic manufacturing & $1.7 \%$ & $\begin{array}{l}\text { Location specific, resource } \\
\text { seeking }\end{array}$ \\
\hline $\begin{array}{l}\text { Other, mostly public and community } \\
\text { services }\end{array}$ & Nontradable & $0.4 \%$ & Other \\
\hline Construction & Infrastructure & $0.4 \%$ & Large market seeking \\
\hline Clothing and footwear & Basic manufacturing & $0.0 \%$ & Other \\
\hline
\end{tabular}

FDI = foreign direct investment, GDP = gross domestic product, GVC = global value chain, US = United States.

Source: Staff calculations using data from fDi Markets. https://www.fdimarkets.com and Haver Analytics (accessed April 2019). 


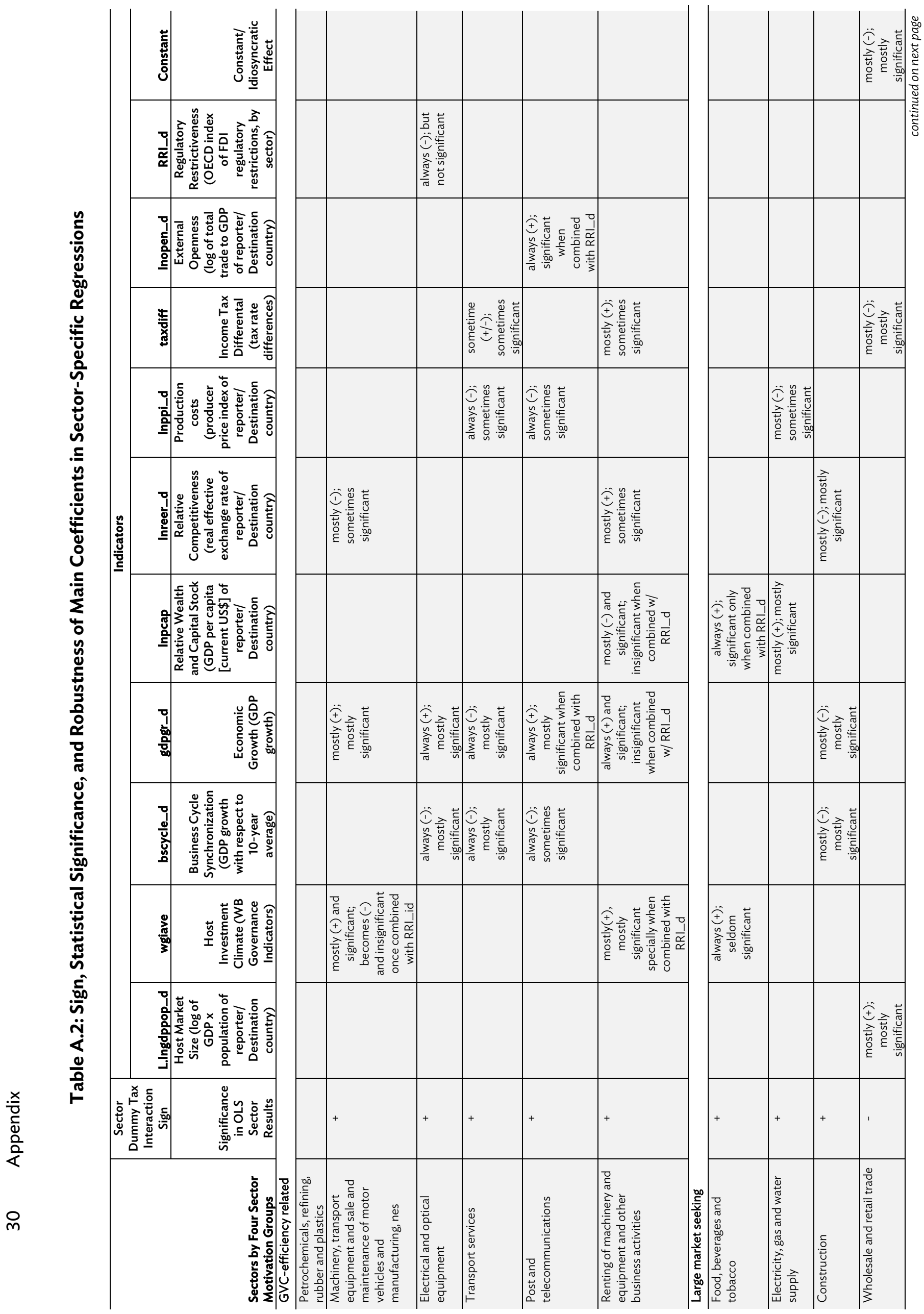




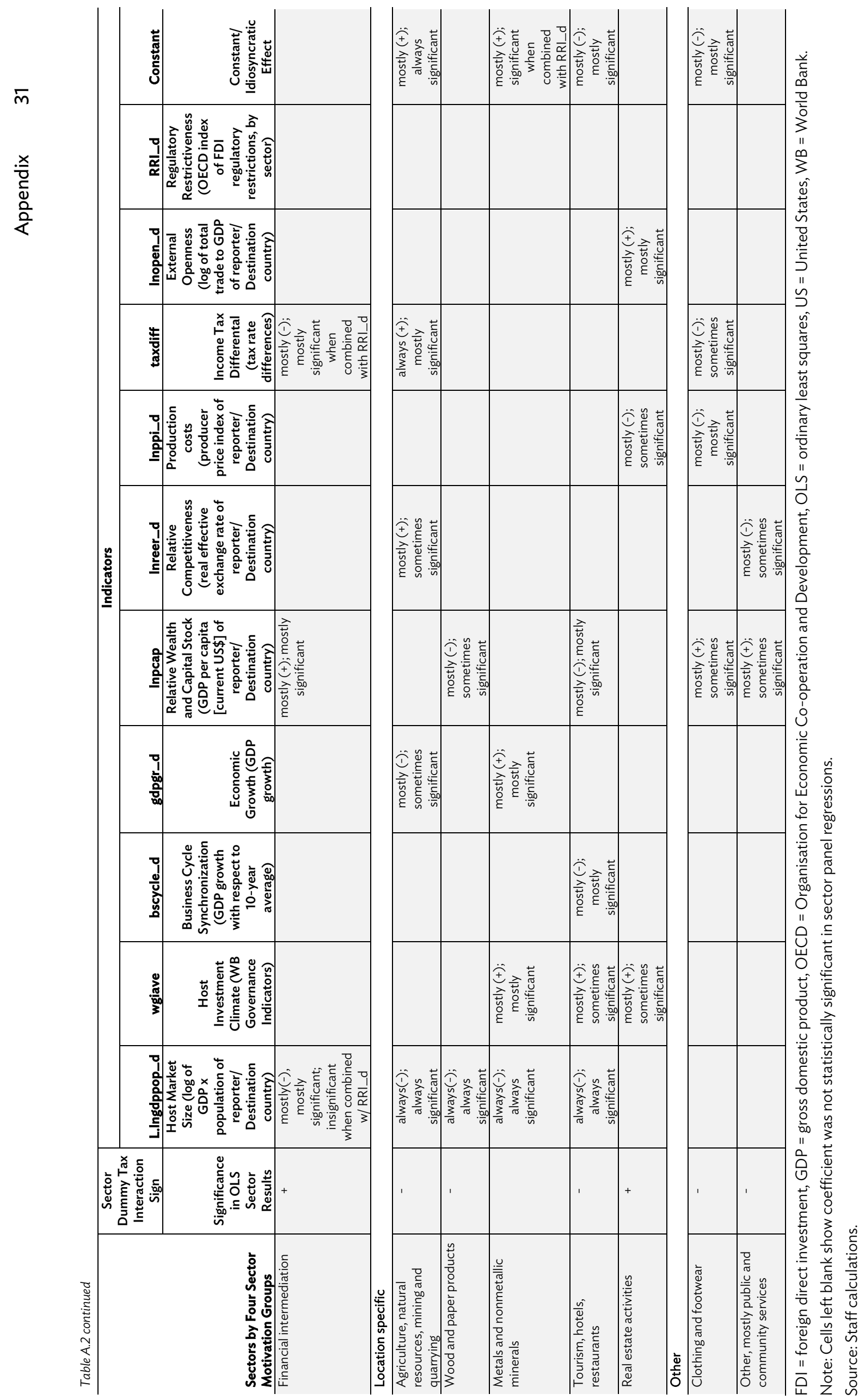




\section{REFERENCES}

Arellano, Manuel and Stephen Bond. 1991. "Some Tests of Specification for Panel Data: Monte Carlo Evidence and an Application to Employment Equations." Review of Economic Studies 58 (2): 277. doi:10.2307/2297968.

Asia Briefing. https://www.asiabriefing.com/news/2014/12/analysis-asias-tax-rates-part-onecorporate-income-tax (accessed March 23, 3018).

2015. Asian Economic Integration Report: What Drives Foreign Direct Investment in Asia and the Pacific? Manila, Philippines, October. www.adb.org.

Asian Development Bank (ADB). 2019a. Asian Development Outlook: Strengthening Disaster Resilience. Manila, Philippines, April. www.adb.org.

- 2019b. Asian Economic Integration Report: Demographic Change, Productivity, and the Role of Technology. Manila, Philippines, November. www.adb.org.

Aziz, Abdul and Bilal Makkawi. 2012. "Relationship between Foreign Direct Investment and Country Population". International Journal of Business and Management, Vol.7, No.8 (April). http://www.ccsenet .org/journal/index.php/ijbm/article/download/13817/10940.

Barrios, Salvador, Harry Huizinga, Luc Laeven, and Gaetan Nicodeme. 2012. "International taxation and multinational firm location decisions”. Journal of Public Economics, Vol. 96 (December): 946-958.

Beck, Stacie, and Alexis Chaves. 2011. "The Impacts of Various Taxes on Foreign Direct Investment". Working Papers 11-18, University of Delaware, Department of Economics. http://graduate.lerner .udel.edu/sites/default/files/ECON/PDFs/RePEc/dlw/WorkingPapers/2011/UDWP2011-18.pdf.

Becker, Amanda, and David Morgan. 2017. "What's in the Final Republican tax bill”. Reuters. 20 December. https://www.reuters.com/article/us-usa-tax-provisions-factbox/whats-in-the-finalrepublican-tax-bill-idUSKBN1ED27K.

Bénassy-Quéré, Agnes, Nicolas Gobalraja, and Alain Trannoy. 2007. "Tax and public input competition”. Economic Policy, CEPR;CES;MSH, Vol. 22 (April): 385-430.

Bureau of Economic Analysis. https://www.bea.gov/international/di1usdbal (accessed April 2019).

Damgaard, Jannik, Thomas Elkjaer, and Niels Johannesen. 2019. "The Rise of Phantom Investments". Finance and Development, Vol. 56, No. 3 (September). https://www.imf.org/external/pubs/ft/fandd/ 2019/09/pdf/the-rise-of-phantom-FDI-in-tax-havens-damgaard.pdf.

De Mooij, Ruud A., and Sjef Ederveen. 2008. "Corporate Tax Elasticities A Reader's Guide to Empirical Findings". Oxford Review of Economic Policy, Vol. 24, Issue 4 (Winter): 680-697. 
Desai, Mihir A., C. Fritz Foley, and James R. Hines. 2002. "Foreign Direct Investment in a World of Multiple Taxes." Harvard Business School Working Paper 03-047 (August). https://wcfia.harvard .edu/files/wcfia/files/577_foreign_direct_investment.pdf.

Desai, Mihir A. and James R. Hines Jr. 2002. "Expectations and expatriations: Tracing the causes and Consequences of Corporate Inversions". National Tax Journal, Vol. 55, No. 3 (September): 409-440. https://www.ntanet.org/NTJ/55/3/ntj-v55n03p409-40-expectations-expatriations-tracingcauses.pdf.

Devereux, Michael P. 2006. "The Impact of Taxation on the Location of Capital, Firms and Profit: A Survey of Empirical Evidence". Working Paper No. 702, Oxford University Centre for Business Taxation. https://core.ac.uk/download/pdf/28878019.pdf.

Djankov, Simeon, Tim Ganser, Caralee McLiesh, Rita Ramalho, and Andrei Shleifer. 2010. "The Effect of Corporate Taxes on Investment and Entrepreneurship". American Economic Journal: Macroeconomics, Vol. No. 3 (July): 31-64. http://www.aeaweb.org/articles.php?doi=10.1257/mac.2.3.31.

Echandi, Roberto, Jana Krajcovicova, and Christine Zhenwe Qiang. 2015. "The impact of investment policy in a Changing Global Economy: A Review of the Literature". Policy Research Working Paper Series 7437, The World Bank. http://documents.worldbank.org/curated/en/664491467994693599/ pdf/WPS7437.pdf.

Feld, Lars, and Jost H. Heckemeyer. 2008. "FDI and Taxation, A Meta-Study”. ZEW Center for European Economic Research Discussion Paper No. 08-128.

Hassett, Kevin, and Gilbert Metcalf. 1999. "Investment with Uncertain Tax Policy: Does Random Tax Policy Discourage Investment?” Economic Journal, Royal Economic Society, Vol. 109, Issue 457 (July): 372-393.

Head, Keith, Thierry Mayer, and John Ries. 2010. "The erosion of colonial trade linkages after independence," Journal of International Economics, Elsevier, Vol. 81, No. 1 (May): 1-14.

Hebous, Shafik, Martin Ruf, and Alfons Weichenrieder. 2010. "The Effects of Taxation on the Location Decision of Multinational Firms: M\&A vs. Greenfield Investments.” CESifo Working Paper 3076. Munich, Germany. https://www.cesifo-group.de/DocDL/cesifo1_wp3076.pdf.

- 1996. Altered states: Taxes and the location of foreign direct investment in America, American Economic Review, American Economic Association, Vol. 86, No. 5 (December): 1076-1094.

Hines, James R., Jr. 2017. "Business Tax Burdens and Tax Reform". Brookings Papers on Economic Activity, Economic Studies Program. The Brookings Institution, Vol. 48, No. 2 (Fall): 449-471. https://www.brookings.edu/wp-content/uploads/2018/02/hinestextfa17bpea.pdf.

Holtz-Eakin, Douglas, Whitney Newey, and Harvey Rosen. 1988. "Estimating Vector Autoregressions with Panel Data." Econometrica 56 (6): 1371-95.

Hvozdyk, L. and V. Mercer-Blackman. 2009. "What Determines Investment in the Oil Sector?" IDB Working Paper Series No. 209. Inter-American Development Bank. https://www.eisourcebook.org/ cms/What\%20Determines\%20Investment\%20in\%20the\%200il\%20Sector.pdf. 
James, Sebastian. 2009. "Tax and Non-tax Incentives and Investments: Evidence and Policy Implications". Facility for Investment Climate Advisory Services (FIAS). The World Bank Group. December. https://ssrn.com/abstract=1540074.

Joint Committee on Taxation. 2017. "Macroeconomic Analysis of the "Tax Cut and Jobs Act" as Ordered Reported by the Senate Committee on Finance on November 16, 2017". Congress of the United States. 30 November. JCX-61-17. Washington DC. https://www.jct.gov/publications .html? func $=$ startdown\&id $=5045$.

KPMG. https://home.kpmg/xx/en/home/services/tax/tax-tools-and-resources/tax-rates-online/corporate -tax-rates-table.html (accessed March 23, 2018).

Lamsiraroj, Sasi, and Hristos Doucouliagos. 2015. “Does Growth Attract FDI?”. Economics: The OpenAccess, Open-Assessment E-Journal, Vol. 9, No. 2015-19 (July): 1-35. http://dx.doi.org/10.5018/ economics-ejournal.ja.2015-19.

Markle, Kevin, and Douglas Shackelford. 2014. "The Impact of Headquarter and Subsidiary Locations on Multinationals' Effective Tax Rates”. In Brown, Jeffrey R., ed. Tax Policy and the Economy, Vol. 28: 33-62. National Bureau of Economic Research. https://www.nber.org/chapters/c13051.pdf.

Morisset, Jacques, and Neda Pirnia. 2001. "How Tax Policy and Incentives Affect Foreign Direct Investment: A Review”. Mimeo. Foreign Investment Advisory Service (FIAS), a joint service of the International Finance Corporation and the World Bank.

Obeng, Camara Kwasi. 2014. "Effect of corporate tax on sector specific foreign direct investment in Ghana," MPRA Paper 58454, University Library of Munich, Germany. https://mpra.ub.unimuenchen.de/58454/1/MPRA_paper_58454.pdf.

Organisation for Economic Co-operation and Development. https://www.oecd.org/investment/ fdiindex.htm (accessed March 23, 2018).

Organisation for Economic Co-operation and Development (OECD). 2019. "FDI falls 20\% in the first half of 2019". FDI in Figures 2019. http://www.oecd.org/investment/FDI-in-Figures-October-2019.pdf.

Page, Benjamin R., Joseph Rosenberg, James R. Nunns, and Daniel Berger. 2017. "Macroeconomic analysis of the tax cuts and job cuts as passed by the Senate Finance Committee". Tax Policy Center. Urban Institute \& Brookings Institution. 1 December. https://www.taxpolicycenter.org/sites/default/ files/publication/149651/macroeconomic_analysis_of_the_tax_cuts_and_jobs_act_sfc_0.pdf.

Price Waterhouse Cooper. Worldwide Tax Summaries. https:/www.pwc.com/gx/en/services/tax/ worldwide-tax-summaries.html (accessed March 23, 2018).

__ 2016. "International Comparison of Effective Corporate Tax Rates". Prepared for September 2016 Alliance for Competitive Taxation. September. https://www.edocr.com/v/mjdlde29/ globaldocuments/International-Comparision-of-Effective-Corporate-T.

___. 2017. "Tax Reform Legislation impact on Private Equity.” https://www.pwc.com/us/en/services/ tax/library/insights/tax-reform-legislation-impact-on-private-equity.html. 
Stöwhase, Sven. 2005. "Tax-Rate-Differentials and Sector-Specific Foreign Direct Investment: Empirical Evidence from the EU”. FinanzArchiv Public Finance Analysis. Vol. 61, No.4: 535 - 558. https://www.jstor.org/stable/40913094?seq=1\#metadata_info_tab_contents.

Swenson, Deborah L. 2008. "Multinationals and the Creation of Chinese Trade Linkages." Canadian Journal of Economics, Vol. 41, No. 2 (May): 596-618.

United Nations Conference for Trade and Development (UNCTAD). 2017. World Investment Report 2017. Investment and the digital economy. https://unctad.org/en/PublicationsLibrary/wir2017_en.pdf.

___. 2018a. "Tax Reforms in the United States: Implications for International Investment". Global Investment Trends Monitor. No. 29, Special edition (February). https://unctad.org/en/Publications Library/diaeia2018d2_en.pdf.

___ 2018b. World Investment Report 2018. Investment and industrial policies. https://unctad.org/en/ PublicationsLibrary/wir2018_en.pdf.

___ 2019. World Investment Report 2019. Special economic zones. https://unctad.org/en/Publications Library/wir2019_en.pdf.

United States Bureau of Economic Analysis. U.S. Direct Investment Abroad: Balance of Payments and Direct Investment Position Data. https://www.bea.gov/international/di1usdbal (accessed April 2019).

US Treasury Resource Center. https://www.treasury.gov/resource-center/data-chart-center/tic/Pages/ shcreports.aspx (accessed November 21, 2019).

World Bank. World Governance Indicators. https://info.worldbank.org/governance/wgi/ (accessed April 2019).

Yeyati, Eduardo L.., Ugo Panizza, and Ernesto H. Stein. 2007. "The Cyclical Nature of North-South FDI Flows.” Journal of International Money and Finance, Vol. 26, Issue 1: 104-130.

https://www.sciencedirect.com/science/article/pii/S0261560606001033.

Yücer, A., Siroën, J.-M., Archanskaia, E. 2014. World FTZ Database. https://ftz.dauphine.fr/fr/donnees/ world-ftz-database.html. 


\section{The Impact of United States Tax Policies on Sectoral Foreign Direct Investment to Asia}

Using panel data at the country and sector level spanning almost 15 years, this paper shows that the corporate income tax rate does not affect the United States' inward foreign direct investment once market size, costs, openness, and the business environment, are taken into account. This is true for United States foreign direct investment bound to developing Asia and across most sectors.

\section{About the Asian Development Bank}

ADB is committed to achieving a prosperous, inclusive, resilient, and sustainable Asia and the Pacific, while sustaining its efforts to eradicate extreme poverty. Established in 1966, it is owned by 68 members -49 from the region. Its main instruments for helping its developing member countries are policy dialogue, loans, equity investments, guarantees, grants, and technical assistance. 